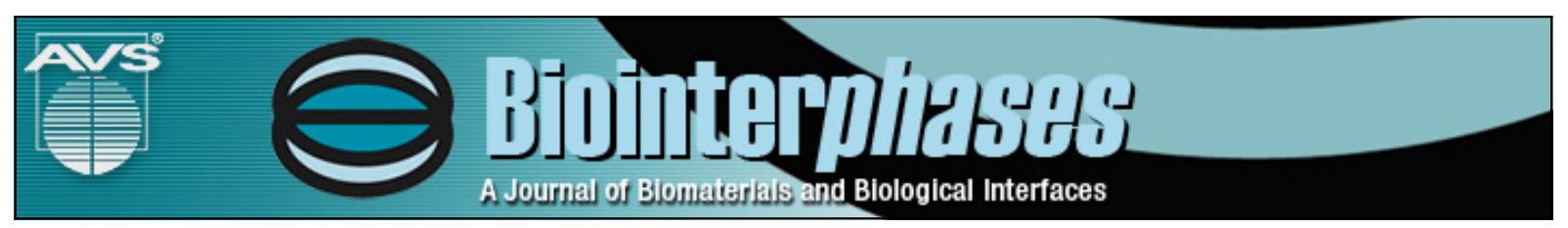

\title{
Identification of the biologically active liquid chemistry induced by a nonthermal atmospheric pressure plasma jet
}

Kristian Wende, Paul Williams, Joe Dalluge, Wouter Van Gaens, Hamada Aboubakr, John Bischof, Thomas von Woedtke, Sagar M. Goyal, Klaus-Dieter Weltmann, Annemie Bogaerts, Kai Masur, and Peter J. Bruggeman

Citation: Biointerphases 10, 029518 (2015); doi: 10.1116/1.4919710

View online: http://dx.doi.org/10.1116/1.4919710

View Table of Contents: http://scitation.aip.org/content/avs/journal/bip/10/2?ver=pdfcov

Published by the AVS: Science \& Technology of Materials, Interfaces, and Processing

\section{Articles you may be interested in}

Optical emission spectroscopic diagnostics of a non-thermal atmospheric pressure helium-oxygen plasma jet for biomedical applications

J. Appl. Phys. 113, 233302 (2013); 10.1063/1.4811339

Atmospheric pressure plasma jet-Living tissue interface: Electrical, optical, and spectral characterization J. Appl. Phys. 113, 183302 (2013); 10.1063/1.4804319

Reactive oxygen species-related plasma effects on the apoptosis of human bladder cancer cells in atmospheric pressure pulsed plasma jets

Appl. Phys. Lett. 101, 053703 (2012); 10.1063/1.4742742

Optical and electrical characterization of an atmospheric pressure microplasma jet for $\mathrm{Ar} / \mathrm{C} \mathrm{H} 4$ and $\mathrm{Ar} / \mathrm{C} 2 \mathrm{H} 2$ mixtures

J. Appl. Phys. 101, 103307 (2007); 10.1063/1.2714646

Measurements of dioxygen fluoride ( $\mathrm{O} 2 \mathrm{~F}$ ) in an atmospheric pressure plasma jet Appl. Phys. Lett. 87, 011502 (2005); 10.1063/1.1968420 


\section{Identification of the biologically active liquid chemistry induced by a nonthermal atmospheric pressure plasma jet}

Kristian Wende ${ }^{\text {a) }}$

Leibniz Institute for Plasma Science and Technology, INP Greifswald e.V., Felix-Hausdorff-Str. 2, 17489

Greifswald, Germany and Department of Mechanical Engineering, University of Minnesota, 111 Church

Street SE, Minneapolis, Minnesota 55455

Paul Williams

Department of Mechanical Engineering, University of Minnesota, 111 Church Street SE, Minneapolis, Minnesota 55455

Joe Dalluge

Department of Chemistry, University of Minnesota, 207 Pleasant St SE, Minneapolis, Minnesota 55455

Wouter Van Gaens

Department of Chemistry, University of Antwerp, Universiteitsplein 1, BE-2610 Antwerp-Wilrijk, Belgium

\section{Hamada Aboubakr}

College of Veterinary Medicine, University of Minnesota, 1333 Gortner Ave., St. Paul, Minnesota 55108 and Food Science and Technology Department, Alexandria University, Aflaton St., El-Shatby, 21545 ,

Alexandria, Egypt

John Bischof

Department of Mechanical Engineering, University of Minnesota, 111 Church Street SE, Minneapolis, Minnesota 55455

Thomas von Woedtke

Leibniz Institute for Plasma Science and Technology, INP Greifswald e.V., Felix-Hausdorff-Str. 2, 17489

Greifswald, Germany

Sagar M. Goyal

College of Veterinary Medicine, University of Minnesota, 1333 Gortner Ave., St. Paul, Minnesota 55108

Klaus-Dieter Weltmann

Leibniz Institute for Plasma Science and Technology, INP Greifswald e.V., Felix-Hausdorff-Str. 2, 17489

Greifswald, Germany

Annemie Bogaerts

Department of Chemistry, University of Antwerp, Universiteitsplein 1, BE-2610 Antwerp-Wilrijk, Belgium

Kai Masur

Center for Innovation Competence Plasmatis, Felix-Hausdorff-Str. 2, 17489 Greifswald, Germany and Leibniz Institute for Plasma Science and Technology, INP Greifswald e.V., Felix-Hausdorff-Str. 2, 17489 Greifswald, Germany

Peter J. Bruggeman

Department of Mechanical Engineering, University of Minnesota, 111 Church Street SE, Minneapolis, Minnesota 55455

(Received 11 February 2015; accepted 23 April 2015; published 6 May 2015)

The mechanism of interaction of cold nonequilibrium plasma jets with mammalian cells in physiologic liquid is reported. The major biological active species produced by an argon RF plasma jet responsible for cell viability reduction are analyzed by experimental results obtained through physical, biological, and chemical diagnostics. This is complemented with chemical kinetics modeling of the plasma source to assess the dominant reactive gas phase species. Different plasma chemistries are obtained by changing the feed gas composition of the cold argon based RF plasma jet from argon, humidified argon (0.27\%), to argon/oxygen (1\%) and argon/air (1\%) at constant power. A minimal consensus physiologic liquid was used, providing isotonic and isohydric conditions and nutrients but is devoid of scavengers or serum constituents. While argon and humidified argon plasma led to the creation of hydrogen peroxide dominated action on the mammalian cells, argon-oxygen and argon-air plasma created a very different biological action and was characterized by trace amounts of hydrogen peroxide only. In particular, for the argon-oxygen (1\%), the authors observed a strong negative effect on mammalian cell proliferation and metabolism. This effect was distance dependent and showed a half life time of $30 \mathrm{~min}$ in a

${ }^{a)}$ Electronic mail: kristian.wende@inp-greifswald.de 
scavenger free physiologic buffer. Neither catalase and mannitol nor superoxide dismutase could rescue the cell proliferation rate. The strong distance dependency of the effect as well as the low water solubility rules out a major role for ozone and singlet oxygen but suggests a dominant role of atomic oxygen. Experimental results suggest that $\mathrm{O}$ reacts with chloride, yielding $\mathrm{Cl}_{2}{ }^{-}$or $\mathrm{ClO}^{-}$. These chlorine species have a limited lifetime under physiologic conditions and therefore show a strong time dependent biological activity. The outcomes are compared with an argon MHz plasma jet (kinpen) to assess the differences between these (at least seemingly) similar plasma sources. (C) 2015 American Vacuum Society. [http://dx.doi.org/10.1116/1.4919710]

\section{INTRODUCTION}

Nonequilibrium atmospheric pressure plasma sources have seen an enormous development in the last decade. ${ }^{1}$ Reactive plasmas at close-to-room temperature allow the treatment of heat sensitive matter, ranging from synthetic polymer materials to living tissues. They are used in medicine for a variety of conditions with good success. ${ }^{2-4}$ Recent developments also include the treatment of food to preserve quality or reduce microbial load. ${ }^{5,6}$ Even so, the key processes leading to these beneficial plasma-biological interactions are poorly understood. ${ }^{7}$

A significant amount of knowledge about the gas phase composition and dynamics of nonequilibrium plasma jets is available $;^{8-11}$ nonetheless, information on the respective plasma-liquid interactions is rather scarce in literature although it is a key step in the interaction of plasmas with biological systems surrounded by liquids. ${ }^{12}$ It is commonly agreed that reactive oxygen and nitrogen species (ROS and RNS) generated in the active plasma, its afterglow, or at the liquid interface play a major role in creating biological effects of cold plasmas. ${ }^{7,13}$ A multitude of oxygen and nitrogen centered radicals have been detected in the gas phase using highly quantitative and selective spectroscopic methods such as laser induced fluorescence and molecular beam mass spectrometry. ${ }^{14,15}$ The liquid phase chemicals induced by the plasma in the solution are primarily investigated by indirect methods including electron spin resonance, colorimetric or fluorescence techniques, which can disturb the system under investigation and/or be highly nonselective. The combination of the plasma induced complex liquid chemistry and the nonselectivity of many analytical methods poses great challenges to unraveling the chemical processes in the solution phase leading to plasma-bio interactions. Along with these obstacles, plasma related chemical reactions can be obscured or modified in complex body fluids or cell culture media, e.g., by scavenging reactions. Hence, the answer to the question of how a certain biological effect was triggered-and by which species_-can be extremely complex. Nonetheless, several species have been suggested to be major in plasma-bio interactions including $\mathrm{H}_{2} \mathrm{O}_{2},{ }^{9,16} \mathrm{O}_{3},{ }^{17}$ peroxynitrite, ${ }^{18} \mathrm{NO}_{2} / \mathrm{NO}^{7} \mathrm{O}_{2}{ }^{-19}$ and singlet oxygen. ${ }^{20}$ These conclusions have often been reached through indirect evidence and discrepancies have been attributed to differences in plasma sources, operation mode, cells, and media.

To shed more light on the tunable and transient nature of the interaction of nonequilibrium plasma jets with biological matter (and, in particular, mammalian cells), this report seeks to identify the major biological active species produced by an argon RF plasma jet through analyzing experimental results obtained from physical, biological, and chemical diagnostics complemented with chemical kinetics modeling of the plasma source. Here, different plasma chemistries were created by changing the feed gas composition from argon or humidified argon to argon-oxygen and argon-air mixtures while keeping the dissipated power constant. It was anticipated that increasing the humidity leads to more $\mathrm{OH}$ and $\mathrm{H}_{2} \mathrm{O}_{2}$ production, increasing the air concentration to more $\mathrm{NO}$, increasing the $\mathrm{O}_{2}$ concentration to more $\mathrm{O}_{3}$. Using a biological assay, ${ }^{21}$ the impact of these different chemistries on mammalian cells was evaluated revealing plasma operational modes producing significantly distinctive biological responses. Subsequently, by modification of the experimental procedure, the use of reactive species scavengers and different buffer systems potential biologically active species were pinpointed and proven further by using chemical or physical detection. The outcomes are compared with the kinpen ${ }^{22}$ to assess the differences between (at least seemingly) similar plasma sources.

\section{MATERIALS AND METHODS}

\section{A. Cell culture and cell viability assay}

Cell culture consumables (T75 flasks, $50 \mathrm{ml}$ centrifuge tubes) were purchased from Sarstedt (Newton, NC, USA). Other plastic material (stripettes) came from Corning (Tewksbury, MA, USA) and Nunc Nalgene (Roskilde, Denmark) (96 well plate, flat bottom). Roswell Park Memorial Institute Medium 1640 (RPMI 1640), phosphate buffered saline w/ $\mathrm{Mg}^{2+} / \mathrm{Ca}^{2+}$ (PBS), trypsin/ethylendiaminetetraacetic acid (EDTA), and fetal bovine serum (FBS) were purchased from Corning (Tewksbury, MA, USA). Eukaryotic epithelial CRFK cells (Crandell-Reese feline kidney, cortex cells) were obtained from ATCC (CCL-94 ${ }^{\mathrm{TM}}$ ).

Complete culture medium was made from RPMI supplemented with penicillin/streptomycin $(100 \mathrm{IU} / \mathrm{ml}$ penicillin; $100 \mu \mathrm{g} / \mathrm{ml}$ streptomycin), $1.2 \mu \mathrm{g} / \mathrm{ml}$ sodium deoxycholate (Fungizone, Life Technologies, Carlsbad, CA, USA), and $8 \%$ heat inactivated FBS. Cells were cultivated in $75 \mathrm{~cm}^{2}$ filter cap cell culture flasks at $37{ }^{\circ} \mathrm{C} / 5 \% \mathrm{CO}_{2}$ in a humidified atmosphere and passaged by trypsinization $(0.025 \%$ trypsin/ EDTA) twice a week.

For the cell viability assay, cells were collected as described above. A cell suspension containing 35000 cells/ 
$\mathrm{ml}$ was prepared in complete medium followed by seeding $100 \mu \mathrm{l}$ into the inner 60 wells of a clear flat bottom 96-well plate using a multichannel pipette. Cells then were allowed to rest for $24 \mathrm{~h}$ in an incubator. Directly before plasma treatment, the medium was discarded and replaced by $100 \mu \mathrm{l}$ of phosphate buffered saline $\mathrm{w} / \mathrm{Ca}^{2+} / \mathrm{Mg}^{2+}$ containing $1 \mathrm{~g} / \mathrm{l} \mathrm{glu}-$ cose. The treatment was achieved by adding $100 \mu \mathrm{l}$ of plasma treated liquid immediately after finishing the plasma treatment (see Sec. II C). After addition of the treated buffer, cells were incubated for $60 \mathrm{~min}$ under standard conditions. ${ }^{21}$ Subsequently, the treated buffer was replaced by fresh complete medium and the cells were incubated for $70 \mathrm{~h}$. The cell viability was determined based on the conversion of 3-(4,5dimethylthiazol-2-yl)-5-(3-carboxymethoxyphenyl)-2-(4-sulfophenyl)-2H-tetrazolium salt (MTS, Promega, Madison, WI, USA) by metabolically active cells according to the manufacturer's protocol. After $45 \mathrm{~min}$, optical density was measured at $490 \mathrm{~nm}$ using a VMax multiplate reader (Molecular Devices, Sunnyvale, CA, USA). All experiments were carried out in duplicate or triplicate with six parallels each. Data were analyzed using MS EXCEL and GRAPHPAD PRISM 5. To allow a better comparison with results from other labs, the biological impact was expressed as plasma treatment intensity $\left(\mathrm{ms} \mu \mathrm{l}^{-1}\right.$ cell $^{-1}$, often given as $U$ ). Details and conditions for the use of this unit are discussed elsewhere. ${ }^{21}$ The $50 \%$ effect level (treatment equivalents, $\mathrm{TE}_{50}$ ) was calculated by sigmoidal regression. The $\mathrm{TE}_{50}$ is defined as the plasma treatment leading to a $50 \%$ reduction of the cell division rate. Because we use a separate plasma treatment and dilutions thereof, the term treatment equivalent was preferred over treatment time.

\section{B. Plasma source}

Two nonequilibrium atmospheric plasma sources were used for the experiments. One was developed in the laboratory of Professor Bruggeman and has been characterized in significant

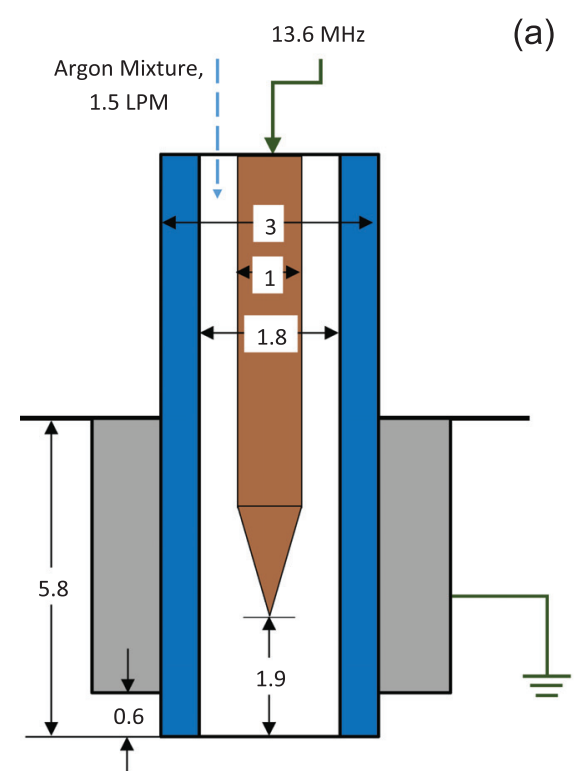

detail including in situ measurements of the gas temperature, electron density, temperature and reactive species densities such as $\mathrm{NO}, \mathrm{O}, \mathrm{O}_{3} \cdot{ }^{11,23}$ Figure 1(a) shows a schematic of the plasma source setup. It consists of an RF driven tungsten needle with a diameter of $1 \mathrm{~mm}$ and a sharpened tip surrounded by a quartz tube with an outer and an inner diameter of 3 and $1.9 \mathrm{~mm}$, respectively. A gas flow of 1.5 standard liters per minute (slm) argon is applied through the tube, if desired with admixtures of molecular gases (oxygen or air) or water saturated argon (saturated by bubbling through distilled disinfected water).

Gases were supplied by Matheson Gas (Montgomeryville, PA, USA) with a purity equal to or better than $99.999 \%$. All gas delivery tubing was made from brass or Teflon. The discharge is ignited using a RF frequency of $13.7 \mathrm{MHz}$ generated by a signal generator (Agilent 33220A, $20 \mathrm{MHz}$ Function Generator, Agilent Loveland, CO, USA) connected to a power amplifier (Amplifier Research 75 W, 5-250 MHz, Souderton, PA, USA). An inductance is connected in series between the high voltage output of the power amplifier and the plasma source in order to match the amplifier to the plasma. The plasma dissipated power was measured as described before. ${ }^{11}$

Alternatively, the so called kinpen was used to perform the plasma treatment. It is an extensively described source in respect to its physical and chemical properties as well as its biological impact (INP Greifswald and ZIK plasmatis). It consists of two electrodes, the $1 \mathrm{~mm}$ rod electrode in the center of a ceramic capillary and a grounded electrode surrounding the dielectric capillary [Fig. 1(b)]. ${ }^{22}$ The jet is operated by high frequency of around $1 \mathrm{MHz}$ applied to the centered electrode. As feed gas, $3 \mathrm{slm}$ argon (argon N50, Air Liquide) was used.

\section{Plasma treatment and sample preparation}

Plasma treatment applying the above mentioned conditions was achieved by the following routine: $3 \mathrm{ml}$ of

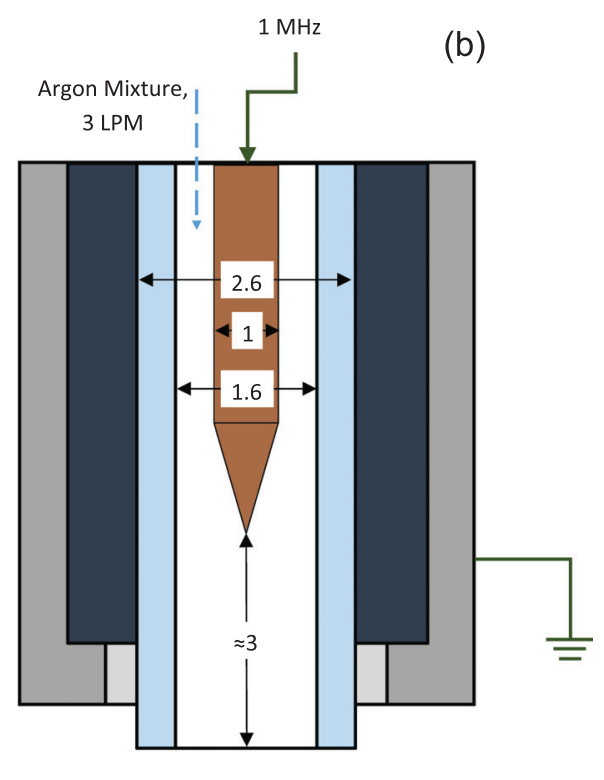

FIG. 1. Schematic of RF plasma jet (a) and kinpen (b) (Ref. 24). In both cases, a visible plume extends about 10 mm from the ignited plasma when Ar is used as working gas. Admixtures of molecular gases or water are possible. 
physiological liquid (phosphate buffered natural saline with $\mathrm{Ca}^{2+} / \mathrm{Mg}^{2+}, 1 \mathrm{~g} / \mathrm{l}$ D-glucose, and $p \mathrm{H} 7.4=$ treatment buffer) was placed into a Corning six-well plate. Using a scissor jack and a digital measuring slide controlled distance treatments were performed. Immediately after treatment was finished ( $<1 \mathrm{~min}$ ), $100 \mu$ l of the liquid were transferred onto the prepared 96 well cell culture plates and diluted serially within the plate as described before. ${ }^{21}$ The procedure is schematically depicted in Fig. 2.

When needed, ROS scavengers were added to the buffer from stock solutions to achieve the respective concentrations: bovine catalase $10 \mathrm{U} / \mathrm{ml}$ or bovine erythrocyte superoxide dismutase (SOD) at $100 \mathrm{U} / \mathrm{ml}$. Additionally, the following organic or inorganic compounds were used: mannitol $(10 \mathrm{mM})$, ammonium iron (II) sulfate $\left(\left(\mathrm{NH}_{4}\right)_{2} \mathrm{Fe}\left(\mathrm{SO}_{4}\right)_{2}\right)$ 5-1000 $\mu \mathrm{M}$, and ascorbic acid, L-histidine, or sodium pyruvate at $3 \mathrm{mM}$. For some experiments, the treated liquid was stored for up to $60 \mathrm{~min}$ before it was placed onto the cells (at room temperature, in darkness). Hydrogen peroxide is frequently detected in plasma treated liquids and was therefore used as experimental control ( $20 \mu \mathrm{M} ; \approx \mathrm{IC}_{75}$ in CRFK cells).

Alternatively, to compare direct and indirect RF jet treatment, $100 \mu \mathrm{l}$ of buffer were treated by the plasma for $1-60 \mathrm{~s}$ in 96 well plates, either with CRFK cells attached (= direct treatment) or without (= indirect treatment). In case of indirect treatment, buffer was transferred to 96 well plates containing cells immediately afterwards. After $1 \mathrm{~h}$, buffer was replaced by complete medium in both treatment variants and cell viability determined as described. Effects of carrier gas flow were checked occasionally using identical setup/gas composition without igniting the plasma. For chemical detection of hydrogen peroxide, nitrite/nitrate, and superoxide, identical conditions for treatment were used and the treated liquid was subjected to the respective detection methods after treatment (see below).

\section{Determination of hydrogen peroxide and $\mathrm{pH}$}

Hydrogen peroxide $\left(\mathrm{H}_{2} \mathrm{O}_{2}\right)$ levels generated by the plasma treatment were measured using the Amplex Red Assay according to the manufacturer's protocol (Life Technologies, Carlsbad, CA, USA). Differing from it, a

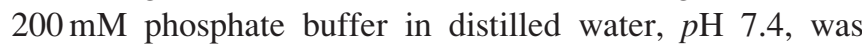
used as assay buffer and diluent. If necessary, the treated liquid was diluted with buffer to keep within the linear detection range of the assay. The measurement was carried out 1 $\mathrm{h}$ after reagent addition using a Biotek Synergy HT fluorescence plate reader (filters: excitation $530 / 25 \mathrm{~nm}$, emission $590 / 35 \mathrm{~nm}$ ). Experiments were carried out in triplicate. Calibration was performed in $200 \mathrm{mM}$ phosphate buffer using authentic hydrogen peroxide dilutions (between 0.16 and $10 \mu \mathrm{M})$. Alternatively, the hydrogen peroxide concentration was measured via its reaction with titanium (IV) oxysulfate $\left(\mathrm{TiOSO}_{4}\right.$ solution, Fluka, Sigma Aldrich, St. Louis, USA). For selected experiments, $p \mathrm{H}$ was measured three times after $10 \mathrm{~min}$ plasma treatment $(8 \mathrm{~mm}$ distance, $1 \mathrm{ml}$ liquid, $\mathrm{Ar}$ or $\mathrm{Ar} / \mathrm{O}_{2} \mathrm{RF}$ jet) using a PerpHecT ROSS micro $p \mathrm{H}$ electrode (Thermo, Beverly, MA, USA).

\section{E. Determination of nitrite/nitrate}

Nitrite $\left(\mathrm{NO}_{2}{ }^{-}\right)$or nitrate $\left(\mathrm{NO}_{3}{ }^{-}\right)$levels were determined by Griess assay according to the manufacturer's protocol (Life technologies, Carlsbad, CA, USA). $\mathrm{NO}_{3}{ }^{-}$was reduced using acidic vanadium (III) chloride $\left(\mathrm{VCl}_{3}, 10 \mathrm{mM}\right.$ final

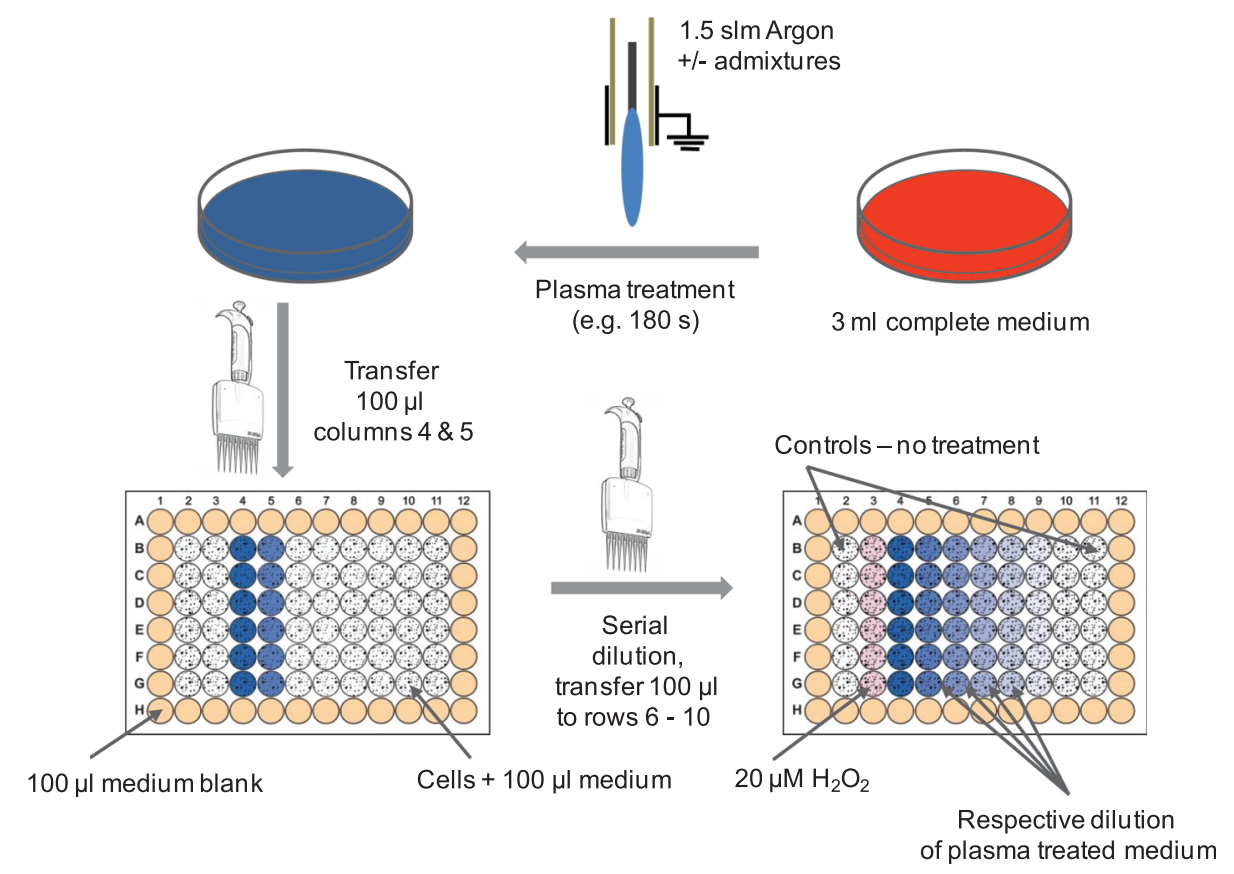

FIG. 2. Indirect (separate) plasma treatment procedure. A physiologic buffer was treated in polystyrene dishes and transferred to cell monolayers prepared in 96-well plates. A serial dilution within the 96-well plate generates different treatment time equivalents. Columns 2 and 11 are left untreated. The outer wells were left intentionally blank (medium only). 
concentration) for $1 \mathrm{~h}$ prior to assay. Sodium nitrite dilutions (between 3.13 and $100 \mu \mathrm{M}$ ) were used as calibrator. Optical density versus blank was determined at $548 \mathrm{~nm}$ using a Spectronic 20D+ photometer (Thermo Scientific, Waltham, MA, USA).

\section{F. Determination of tyrosine nitration}

Nitration of L-tyrosine to 3-nitrotyrosine was used as measure for superoxide or peroxynitrite chemistry created by plasma liquid interaction depending on the presence or absence of a nitric oxide donor. L-tyrosine $(100 \mu \mathrm{M})$ was dissolved in $20 \mathrm{mM}$ phosphate buffer at $p \mathrm{H} 7.3$ containing $100 \mu \mathrm{M}$ sodium diethylene triamine pentaacetic acid. ${ }^{25}$ Diethylamine NONOate (Sigma, St. Louis, MO, USA) was used as a nitric oxide donor $(10 \mu \mathrm{M})$ in some reactions. Subsequently, this mix was exposed to plasma treatment [argon, water saturated argon $(0.27 \%$ water $)$, argon-oxygen (1\%), argon-air (1\%), and argon gas flow only] for $10 \mathrm{~min}$ at a distance of $8 \mathrm{~mm}$ (nozzle-liquid). Immediately after treatment, the solution was snap frozen and stored at $-20^{\circ} \mathrm{C}$ until analysis.

\section{G. Liquid chromatography-electrospray ionization- tandem mass spectrometry}

A waters acquity ultraperformance liquid chromatography (UPLC) coupled to a Waters triple quadrupole mass spectrometer (Acquity TQD) was used for separation and detection of 3-nitrotyrosine. A Waters HSS T3 $2.1 \times 100 \mathrm{~mm}$ column $(1.7 \mu \mathrm{m}$ particles $)$ at $40{ }^{\circ} \mathrm{C}$ was used during the following 9 min gradient separation with (A): water containing $0.1 \%$ formic acid and (B): acetonitrile containing $0.1 \%$ formic acid, at a flow rate of $0.6 \mathrm{ml} / \mathrm{min}: 2 \% \mathrm{~B}, 0-1.0 \mathrm{~min} ; 2 \%$ $\mathrm{B}$ to $18 \% \mathrm{~B}, 1.0-4.0 \mathrm{~min} ; 18 \% \mathrm{~B}$ to $97 \% \mathrm{~B}, 4.0-5.0 \mathrm{~min}$; $97 \%$ B, 5.0-6.0 min; $97 \%$ B to $2 \%$ B, 6.0-7.0 min; and $2 \%$ $\mathrm{B}, 7.0-9.0 \mathrm{~min}$. By directly infusing nitrotyrosine and the internal standard ${ }^{13} \mathrm{C}_{6}$-nitrotyrosine, cone voltages and collision energies for each selected reaction monitoring transition were optimized. The transitions that produced the highest sensitivity for the determination of each analyte were selected for quantification: Nitrotyrosine: $227.2-181.0 ;{ }^{13} \mathrm{C}_{6^{-}}$ nitrotyrosine: 233.2-187.0. Dwell time for each transition was $0.05 \mathrm{~s}$. For electrospray ionization tandem mass spectrometry (ESI-MS/MS) in positive ionization mode, parameters were as follows: capillary, $3.0 \mathrm{kV}$; cone, $25 \mathrm{~V}$; extractor, $1 \mathrm{~V}$; rf lens, $0.3 \mathrm{~V}$; source temperature, $120^{\circ} \mathrm{C}$; desolvation temperature, $500{ }^{\circ} \mathrm{C}$; desolvation flow, $800 \mathrm{l} / \mathrm{h}$; cone gas flow, $20 \mathrm{l} / \mathrm{h}$; low-mass resolution (Q1), $15 \mathrm{~V}$; high-mass resolution (Q1), $15 \mathrm{~V}$; ion energy (Q1), $0.2 \mathrm{~V}$; entrance $-1 \mathrm{~V}$; exit, $5 \mathrm{~V}$; collision energy $12 \mathrm{~V}$; low-mass resolution (Q2), $15 \mathrm{~V}$; high-mass resolution (Q2), $15 \mathrm{~V}$; and ion energy (Q2) $3.5 \mathrm{~V}$.

For standardization, five levels of calibration mixtures ranging from 0 to $450 \mu \mathrm{M}$ were prepared for nitrotyrosine and ${ }^{13} \mathrm{C}_{6}$-nitrotyrosine to achieve five different response ratios for nitrotyrosine in the mixtures. These solutions were then analyzed by UPLC-MS/MS, and the data were subjected to a linear least squares analysis with the Waters TARGETLYNX $^{\mathrm{TM}}$ software program. The peak area ratios of analyte/internal standard were then used in conjunction with the calibration curves to determine the concentration of 3nitrotyrosine in the samples.

\section{H. Plasma chemical kinetics model}

The numerical model used in this study is based on the original GlobalKin source code, developed by Kushner. ${ }^{26}$ The model is used to simulate a plug flow representation of the jet. We divide this cylinder in segments with lengths that correspond to the distance that such a segment would move along the effluent within one time-step (order of $\mu \mathrm{s}$ ) according to the flow speed of the gas at that position. The plasma properties for each cylinder segment are global averages over the volume of that cylinder segment. The model has as input experimentally obtained gas temperature profiles, power distribution derived from emission profiles as described in detail in Ref. 27 and a separately calculated flow field which includes air admixing in the core jet.

A large $\mathrm{Ar} / \mathrm{N}_{2} / \mathrm{O}_{2} / \mathrm{H}_{2} \mathrm{O}$ reaction set of 85 species, interacting by means of 302 electron impact reactions and 1626 heavy particle reactions is implemented, necessary to calculate the densities of biomedically active species at relatively low concentrations and for a broad parameter range. The reactions with this species are listed in Ref. 28. The modeling results have been compared with in situ measurements of $\mathrm{NO}, \mathrm{O}$, and $\mathrm{O}_{3}$ with excellent agreement. ${ }^{27}$ Note that the results are obtained for a free jet and local disturbances of the flow by the solution have not been considered. The modeling outcomes should thus be seen as a semiquantitative representation of the actual measurement conditions.

\section{RESULTS AND DISCUSSION}

\section{A. Motivation of treatment approach}

The argon RF plasma jet produces heat, UV radiation, reactive neutral species, electric fields and radicals which can all contribute to the biological interaction. While the gas temperature is higher than room temperature, the temperature of the treated liquid does not increase even at short distances. On the contrary, we observed a decrease of the bulk temperature from 24 to $22.5^{\circ} \mathrm{C}(120 \mathrm{~s}$ treatment, $3 \mathrm{ml}$ buffer, $8 \mathrm{~mm}$ distance) due to flow enhanced evaporation effects which dominate heat transfer from the active plasma to the liquid. As the plasma is operated in nontouching mode, electric fields at the water surface are moderate and do not penetrate into the liquid due to the high conductivity of the solution. By comparing mass spectrometry measurements of ions and neutrals ${ }^{29}$ complemented with the electron density measurements in the plasma, ${ }^{30}$ the fluxes of ionic species at a typical distance of $8 \mathrm{~mm}$ from the visible plasma plume are approximately five orders of magnitude lower than the flux of neutral reactive species such as $\mathrm{NO}$ and $\mathrm{O}_{3}$.

The plasma emits a considerable fraction of the inserted energy as radiation from the visible down to vacuum UV. Vacuum UV, which is in an argon plasma predominantly 
due to excimer radiation at $125 \mathrm{~nm}$ (Ref. 31) does not penetrate water and triggers photolysis of water molecules at the gas-liquid interface. Thus, reactive oxygen species are created by the homolytic dissociation of $\mathrm{H}_{2} \mathrm{O}$, creating hydroxyl radicals and atomic hydrogen. Recombination reactions lead to the formation of gaseous molecular hydrogen and hydrogen peroxide. ${ }^{32}$ In the case of the argon RF jet, the emitted vacuum ultraviolet light (VUV) triggered creation of small amounts of $\mathrm{H}_{2} \mathrm{O}_{2}$ when treating distilled water. The impact on CRFK cell proliferation rate was negligible, leading to the assumption that no other bioactive species had been created in significant amounts. In neutral $p \mathrm{H}$ (treatment buffer) no effect of VUV radiation on $\mathrm{H}_{2} \mathrm{O}_{2}$ production or cell proliferation rate could be detected (data not shown). This indicates that photolysis of water does not to play a role on the biological effects described in the present work. On the other hand, UV radiation $>200 \mathrm{~nm}$ can penetrate the liquid and has a broad range of effects in biological systems. ${ }^{33-35}$ Depending on the wavelength, it allows photochemical reactions in biopolymers, e.g., nucleic acids (formation of cyclobutanes by dimerizing pyrimidine bases). Recently, it was shown that secondary chemistry can be created by the exposure of UV light emitting diodes (LEDs) on plasma treated water. ${ }^{36}$ The LED luminescence is, however, significantly larger than what is observed for the RF jet and it has been shown that the amount of produced UV was significantly below the biological active threshold. ${ }^{37}$

In view of the above, for the present conditions, the plasma induced liquid phase chemistry is anticipated mainly through neutral reactive species. Eliminating any direct effect of UV can be achieved by treating the solution without cells and adding the solution to the cell medium as performed in this work. The approach enabled a quick and reproducible treatment of cells in a 96 well plate and allowed an easy correlation with chemical assays. In vitro/ex vivo findings in different model systems of Bekeschus, ${ }^{38}$ Schmidt, ${ }^{39}$ and Wende et al. ${ }^{21}$ further indicated, that a separate treatment of liquids provokes the same biological effect as a direct treatment at least for the kinpen. The same effect has been observed for the plasma jet studied in this work (see Fig. 3). No impact of the treatment scheme on cell proliferation rate was detected in case of argon RF jet. Accordingly, comparably long-lived reactive species seem to be the dominant bioactive components in this case. This is in good agreement with work from Kalghatgi, ${ }^{40}$ Graves, ${ }^{7}$ and Lukes. ${ }^{41}$

The impact of (plasma generated) reactive species on cell physiology depends on their concentration and spatial distribution, the composition of the liquid surrounding the cells during treatment, and cell type specific constraints. Mammalian cells are differently well equipped with scavenger systems to control ROS deriving from internal or external sources. ${ }^{42}$ Because the cell proliferation rate is influenced by a sum of factors, e.g., protein, lipid, and DNA integrity, metabolic activity, and overall cell functionality, it can serve as a measure for the overall biological impact of a chemical, biological, or physical treatment. ${ }^{21}$ Data are

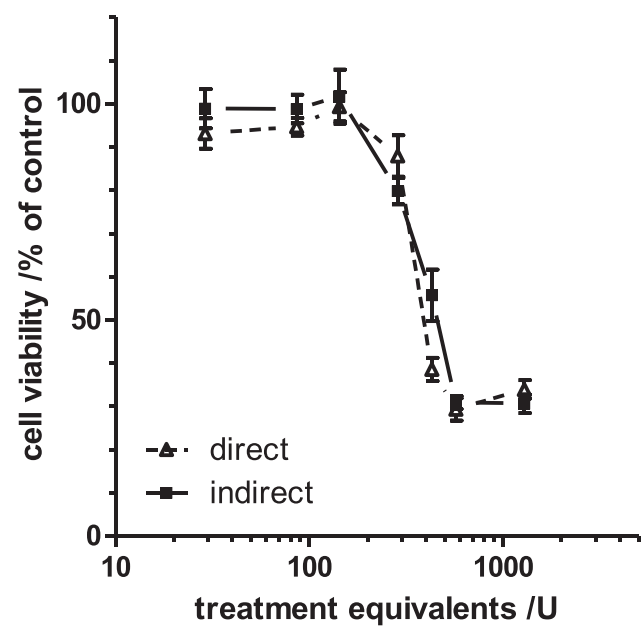

FIG. 3. Comparison of direct vs indirect plasma treatment in 96-well plate (RF plasma jet, $2.5 \mathrm{~W}, 1.5 \mathrm{slm}$ argon, and $16 \mathrm{~mm}$ distance from nozzle to liquid). Data represent mean/ $\pm \mathrm{SD}$ of three experiments with six replicates each.

shown as $\mathrm{IC}_{50}$ (concentration of a chemical which reduces the cell proliferation to 50\%) or $\mathrm{TE}_{50}$ (plasma treatment equivalents reducing proliferation to $50 \%$ ). In this study, we used the CRFK feline kidney cells as a well-established mammalian epithelial model. These cells are sensitive toward exogenous stress signals like ROS as indicated by the $\mathrm{IC}_{50}$ of $\mathrm{H}_{2} \mathrm{O}_{2}\left(15 \pm 2.5 \mu \mathrm{M}\right.$, Fig. 4). ${ }^{43}$ In comparison, human epithelial $\mathrm{HaCaT}$ cells are less sensitive and show an $\mathrm{IC}_{50}$ of $23 \pm 2 \mu \mathrm{M}$ (Fig. 4). ${ }^{9,44}$

As an advantage, CRFK cells compensate growth factor deprivation better than HaCaTs and do not show a cell cycle block after $1 \mathrm{~h}$ of incubation in serum free buffers (data not shown).

Because previous experiments revealed a major influence of the liquid present before, during, or after plasma treatment, RPMI 1640 cell culture medium was chosen for its

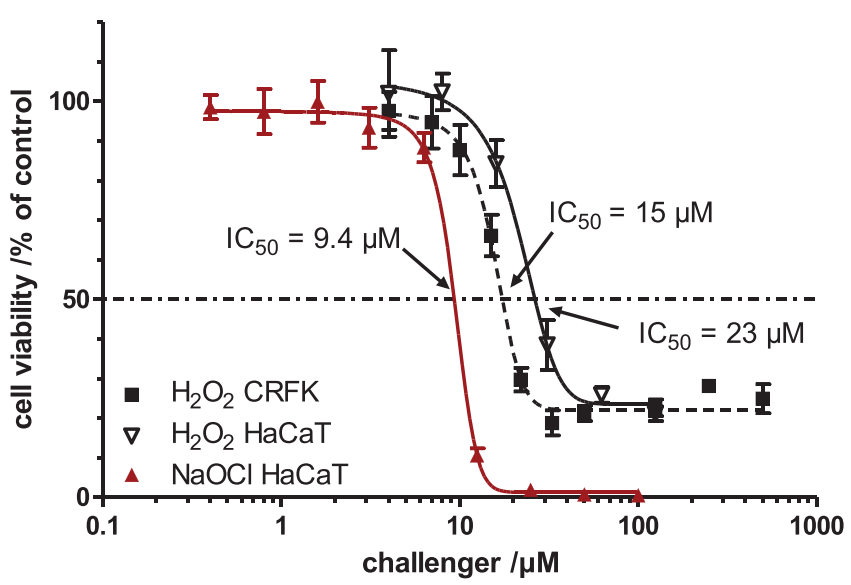

FIG. 4. CRFK feline kidney cells (black squares) are more susceptible than $\mathrm{HaCaT}$ human keratinocytes (open triangles) to hydrogen peroxide $\left(\mathrm{H}_{2} \mathrm{O}_{2}\right)$. Sodium hypochlorite $(\mathrm{NaOCl})$ decreases $\mathrm{HaCaT}$ proliferation very potently, shows a strong threshold effect, and no residual cell viability at high concentrations (upright triangles, red curve). Data represent mean/ $\pm \mathrm{SD}$ of three experiments with six replicates each. 
low ROS scavenging capacity..$^{21,41,45}$ To reduce the complexity and to facilitate the detection of chemical species, the suitability of minimal buffers was tested against the complete RPMI (standard, Fig. 5). All liquids used showed an acceptable cell performance; however, reproducibility and cell sensitivity varied [see Fig. 5(a)]. When treated in Hanks buffered saline solution (HBSS), with $1 \mathrm{~g} / \mathrm{l}$ D-glucose, cell sensitivity increased markedly compared to complete RPMI (data not shown). This effect was attributed to the deprivation of $\mathrm{CO}_{2}$ from the carbonate buffer system present in HBSS causing a nonphysiological $p \mathrm{H}(>8)$. The same $p \mathrm{H}$ deterioration was observed if RPMI without FBS supplementation was used [Fig. 5(b)], filled upright triangles]. In contrast, when using PBS with calcium and magnesium no changes in $p \mathrm{H}$ during handling were observed. The liquid showed a good and reproducible performance in the assay, especially when supplemented with $1 \mathrm{~g} / \mathrm{l}$ D-glucose [Fig. 5(b), diamonds/ downright triangles].

Therefore, to exclude artifacts and to retain residual physiological conditions, subsequent experiments were conducted in PBS glucose as a minimal consensus physiologic liquid. Performed this way the MTS cell viability assay had a good sensitivity and robustness allowing the intended use of CRFK proliferation as a biosensor.

\section{B. Argon RF plasma case and comparison with kinpen}

Figure 6(a) compares the deposition of $\mathrm{H}_{2} \mathrm{O}_{2}$ in treatment buffer by the argon RF plasma jet and kinpen under varying distance between nozzle and liquid. Depending on the distance and plasma source, a $60 \mathrm{~s}$ treatment was found to deposit between 15 and $250 \mu \mathrm{M} \mathrm{H}_{2} \mathrm{O}_{2}$. Alongside, biological impact increases with decreasing distance in case of the RF jet treatment. There is a transition in plasma liquid interaction between 10 and $11 \mathrm{~mm}$ distance were cell proliferation rate jumps down significantly [Fig. 6(b)]. This is a result of the parallel increase in $\mathrm{H}_{2} \mathrm{O}_{2}$ deposition. How this step is created is yet undetermined. The major role of $\mathrm{H}_{2} \mathrm{O}_{2}$ in $\mathrm{RF}$ plasma triggered biological activity becomes evident if the treatment intensity is plotted as $\mu \mathrm{M} \mathrm{H} \mathrm{H}_{2} \mathrm{O}_{2}$ (from measured values) instead of the time based treatment intensity scale [Fig. 6(c)]. All curves then overlap and an $\mathrm{IC}_{50}$ of around $10 \pm 2.5 \mu \mathrm{M}$ was found. This is somewhat lower than expected for authentic $\mathrm{H}_{2} \mathrm{O}_{2}(15 \mu \mathrm{M}$, Fig. 4). This can be an indication that other ROS may be present after plasma treatment. ${ }^{46}$ However, the $100 \%$ rescue observed by the presence of catalase seems to indicate that $\mathrm{H}_{2} \mathrm{O}_{2}$ is the sole ROS active under these treatment conditions [Figs. 4 and 8(a)].

Yet, hydrogen peroxide can be seen as a precursor, leading to more active species by secondary reactions (e.g., Haber-Weiss or Fenton reaction), such as $\mathrm{OH}$ radicals. This assumption was tested by adding $\mathrm{Fe}^{2+}$ to the treatment buffer. However, no increase in the biological effect was observed. In contrast, the cell proliferation rate increased with increasing $\mathrm{Fe}^{2+}$ concentration (Fig. 7 and Table I).

This indicates a consumption of free $\mathrm{H}_{2} \mathrm{O}_{2}$ by Fenton reaction and in parallel a rapid scavenging of the generated $\mathrm{OH}$ radicals by organic molecules present in the treatment buffer (glucose, impurities), leading to a decrease of the observable effect in contrast to the expected increase. Addition of mannitol $(10 \mathrm{mM})$ as an $\mathrm{OH}$ radical scavenger did not change the biological impact (Table I). Both observations emphasize the role of the more stable $\mathrm{H}_{2} \mathrm{O}_{2}$ for plasma generated effects on mammalian cells.

A similar correlation between $\mathrm{H}_{2} \mathrm{O}_{2}$ deposition in liquids and impact on cell proliferation has been reported previously for the kinpen. ${ }^{9}$ In contrast to the RF jet, no distance dependence of typical solution-nozzle spans $(7-28 \mathrm{~mm})$ on the biological impact was observed [Figs. 6(b) and 6(d)]. The $\mathrm{H}_{2} \mathrm{O}_{2}$ production rate of the kinpen was found almost independent on the distance between nozzle and liquid when compared to the strong distance dependency found in case of the RF jet [Fig. 6(a)]. However, the shortest distance measured (7 mm) deposited significantly less $\mathrm{H}_{2} \mathrm{O}_{2}$ than all higher distances, which do not differ from each other. This can be explained by the small amount of ambient species which have traveled into the core effluent at short distance after nozzle. ${ }^{47}$ From
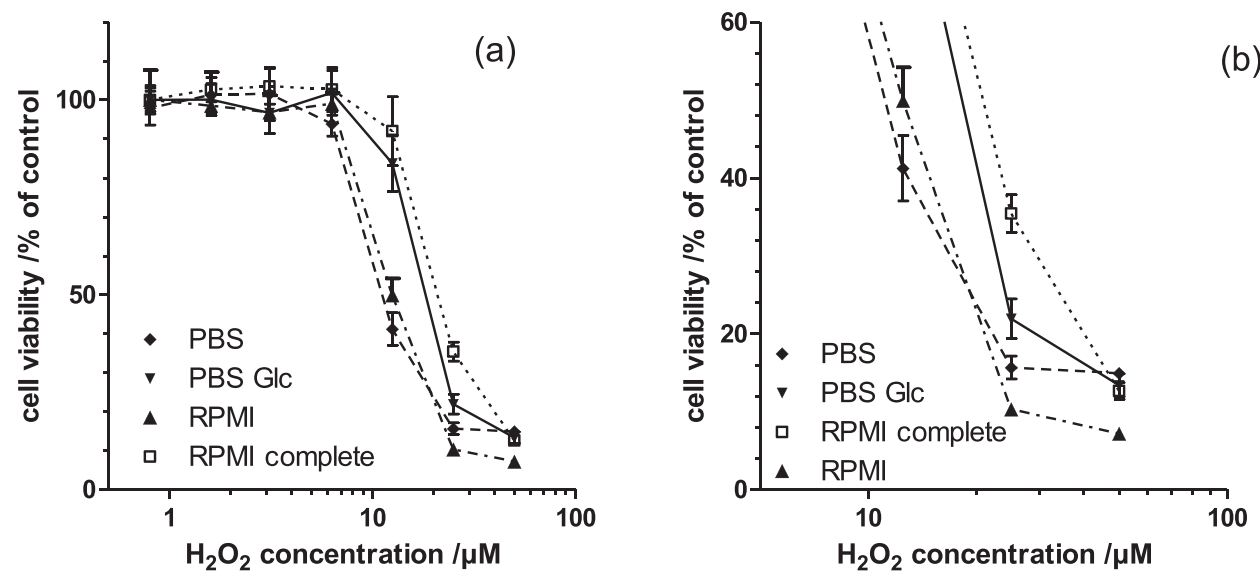

FIG. 5. Comparison of four different solutions with respect to ROS impact. (a) Similar behavior of PBS and RPMI w/o additives which lead to high cell sensitivity. In complete RPMI and PBS + Glc cells show a similar normal sensitivity. (b) Enlarged section of (a) shows cells are more exposed in PBS Glc than RPMI complete. Data represent mean/ $\pm \mathrm{SD}$ of three independent experiments/three replicates each. 

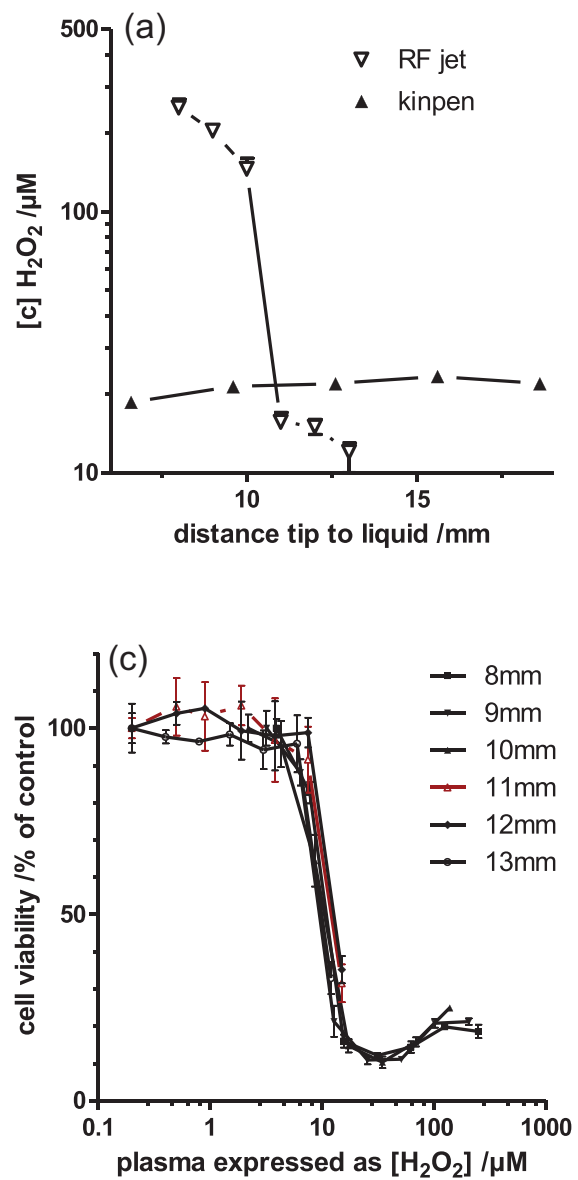
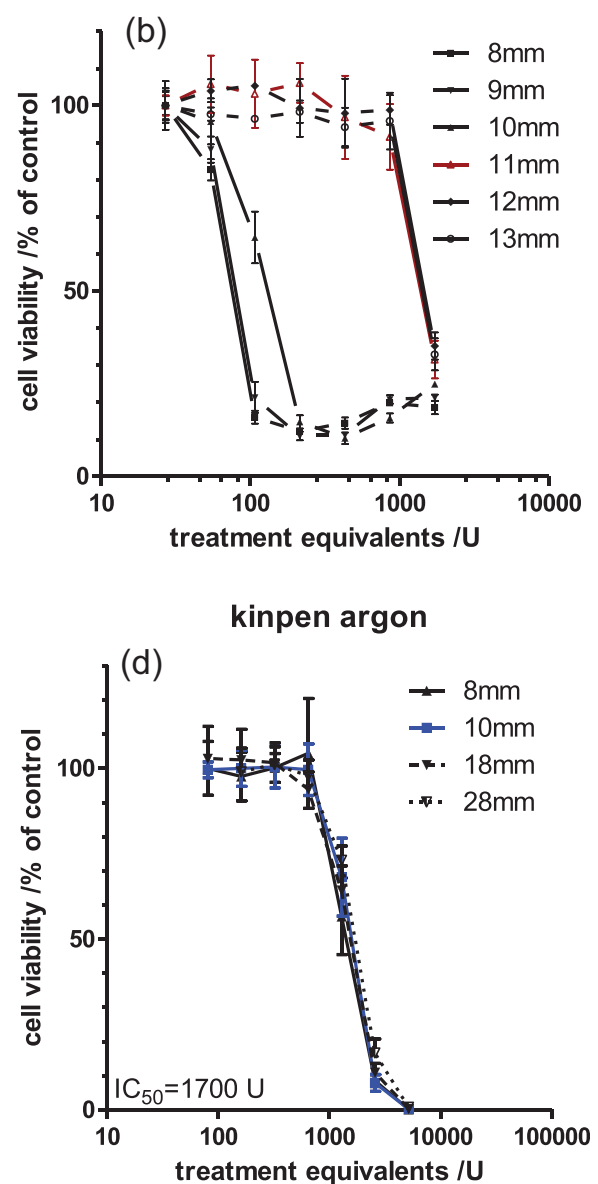

FIG. 6. (a) Production of $\mathrm{H}_{2} \mathrm{O}_{2}$ in PBS $1 \mathrm{~g} / 1$ Glc as a function of the distance nozzle-solution Ar RF jet or kinpen, $60 \mathrm{~s}$ treatment. [(b) and (c)] The biological impact of Ar RF jet increases with decreasing distance but if plotted as $\mathrm{H}_{2} \mathrm{O}_{2}$ impact of plasma treatment is seemingly independent from distance and curves overlap. (d) No distance effect on biological impact was observed for the kinpen argon jet. Data represent mean + range (a) or mean/ \pm SD [(b)-(d)] of two (a) or three [(b)-(d)] experiments with six replicates each.

the perspective of biological impact, this difference was not distinctive [Fig. 6(d)].

\section{Plasma chemistry triggered by water, oxygen, or air admix}

Figure 8 shows the treatment of the CRFK cells with the addition of $1 \% \mathrm{O}_{2}, 1 \%$ air, and $0.27 \%$ water added to the pure argon feed gas compared to the argon case for a fixed nozzle-solution distance of $8 \mathrm{~mm}$. Catalase is used to assess if other reactive species than $\mathrm{H}_{2} \mathrm{O}_{2}$ contribute to the reduction in the observed cell viability. In the case of $\mathrm{Ar}$ and $\mathrm{Ar}+0.27 \% \mathrm{H}_{2} \mathrm{O}$ plasma treatment the addition of catalase leads to a full recovery of the cell viability [Figs. 8(a) and 8(b)], while this is not the case for $\mathrm{Ar} / \mathrm{air}$ and $\mathrm{Ar} / \mathrm{O}_{2}$ plasma [Figs. 8(c) and 8(d)].

Interestingly, a striking difference is observed between adding air and $\mathrm{O}_{2}$ to the Ar RF plasma jet: adding air does not lead to a $100 \%$ reduction in cell viability up to $7700 \mathrm{U}$ treatment equivalents (TE), while adding $\mathrm{O}_{2}$ does for TEs of only 1029 U [Figs. 8(c) and 8(d)].

The calculated densities of the major reactive species in the plasma as a function of axial distance for the four different gas compositions are shown in Fig. 9. The model calculations for the $\mathrm{Ar} / \mathrm{O}_{2}$ and $\mathrm{Ar} /$ air RF plasma have been compared with gas phase species density measurements. ${ }^{23,27}$ The plasma conditions are the same as used in Fig. 8; however, the calculations are made for a free jet without the disturbance of the flow field by the liquid. As anticipated, the

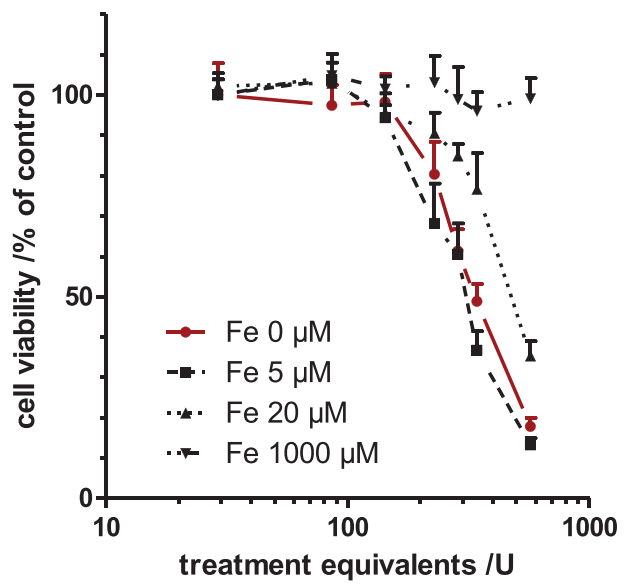

FIG. 7. Plasma treatment with added $\mathrm{Fe}^{2+}$ to test the role of $\mathrm{OH}$ by Fenton's reaction (direct treatment, $16 \mathrm{~mm}$ distance nozzle-liquid PBS $1 \mathrm{~g} / \mathrm{l} \mathrm{Glc}$ ). A decrease of the plasma effect is found with increasing $\mathrm{Fe}^{2+}$ concentration. Data represent mean/ $\pm \mathrm{SD}$ of two experiments with six replicates each. 

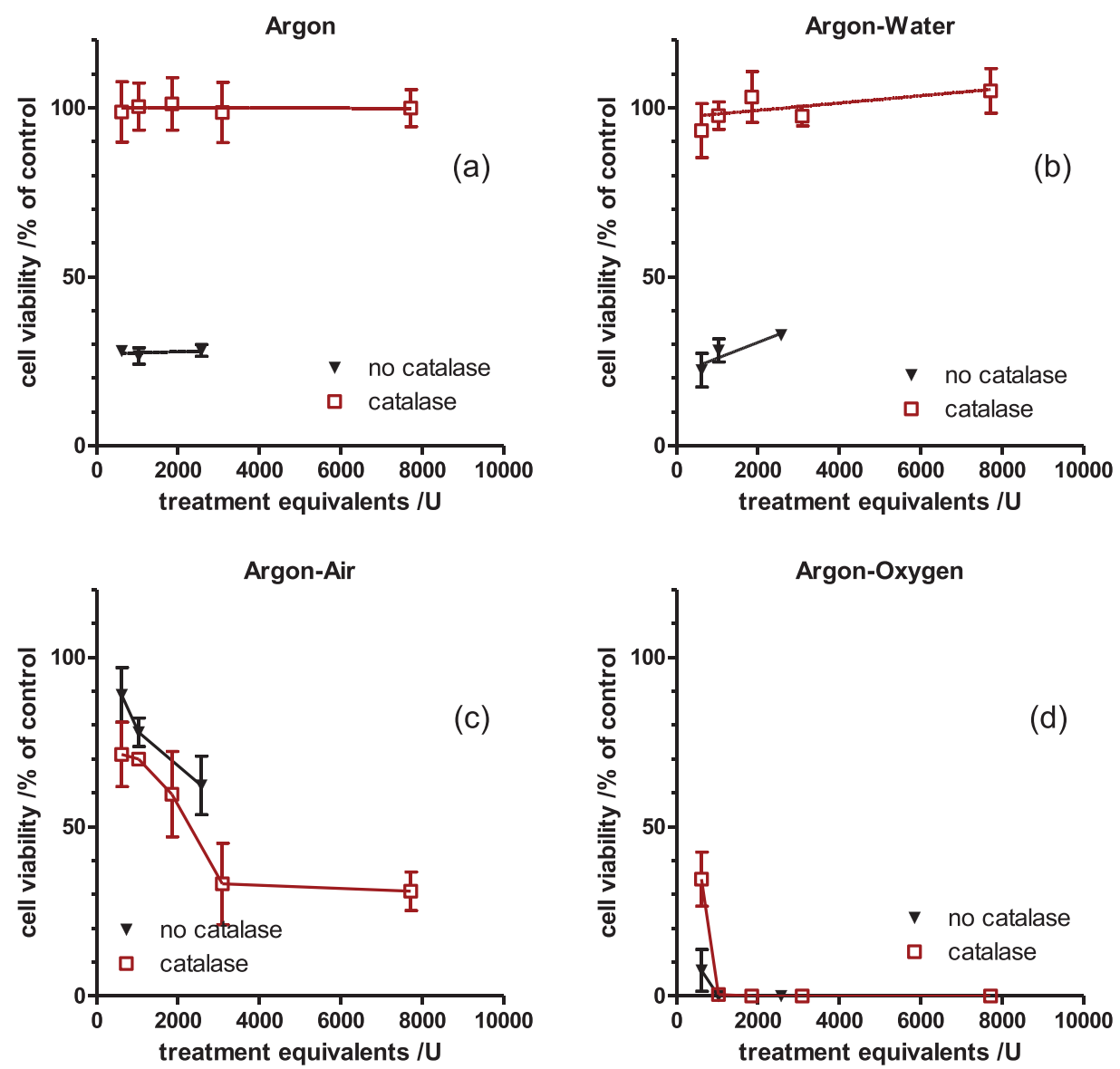

FIG. 8. Treatment of the CRFK cells in PBS $1 \mathrm{~g} / \mathrm{l} \mathrm{Glc}$ for the RF jet in $\mathrm{Ar}(\mathrm{a}), \mathrm{Ar} / 0.27 \%$ water (b), $\mathrm{Ar} / 1 \%$ air (c), and $\mathrm{Ar} / 1 \% \mathrm{O}_{2}$ (d). The distance between nozzle and solution was kept at $8 \mathrm{~mm}$ to maximize treatment intensity. The respective effect of adding the $\mathrm{H}_{2} \mathrm{O}_{2}$ scavenger catalase (10 U/ml) is also shown [red lines/squares, (a)-(d)]. Data represent mean/ \pm SD of three [(a) and (d)] or two [(b) and (c)] experiments with six replicates each.

$\mathrm{OH}$ radical and $\mathrm{H}_{2} \mathrm{O}_{2}$ concentrations in the case for adding $\mathrm{H}_{2} \mathrm{O}$ increase [Fig. 9(b)]. The major differences between argon [Fig. 9(a)] and Ar/air plasma [Fig. 9(c)] are the increased amount of RNS (particularly NO). The major differences between $\mathrm{Ar} /$ air and $\mathrm{Ar} / \mathrm{O}_{2}$ plasma [Fig. 9(d)] are the significant increase in atomic $\mathrm{O}$ density close to the nozzle and the increase of $\mathrm{O}_{3}$ and singlet oxygen. $\mathrm{O}_{3}$ and singlet oxygen do not show a prominent distance dependent variability as is the case for atomic oxygen. These differences seem to trigger significant impact on the plasma induced reactive liquid phase chemistry. Important to note is that the diffusion of surrounding air in the jet effluent leads to RNS (particularly NO) in all cases, even if no air is added to the argon feed gas.

The measurement of $\mathrm{H}_{2} \mathrm{O}_{2}$ deposition by the Amplex Red or titanium oxosulfate assay clearly indicates the major role of this ROS not only in the argon but also the argon-water plasma conditions. The addition of $\mathrm{H}_{2} \mathrm{O}$ to the working gas led to a significant increase in $\mathrm{H}_{2} \mathrm{O}_{2}$ concentration in the plasma treated solution [Fig. 10(a)]. For a treatment time of $60 \mathrm{~s} \mathrm{a} \mathrm{H}_{2} \mathrm{O}_{2}$ concentration around $190 \mu \mathrm{M}$ is found, which is well above the $\mathrm{IC}_{50}$ value of the $\mathrm{H}_{2} \mathrm{O}_{2}$ control of $15 \mu \mathrm{M}$ (Fig. 4). In case of the plasma containing air or oxygen admixture, no $\mathrm{H}_{2} \mathrm{O}_{2}$ deposition in PBS Glc could be detected by either Amplex Red assay [Fig. 10(a)], nor titanyl sulfate, nor metavanadate reagent (data not shown). The addition of sodium azide to scavenge potentially presents $\mathrm{NO}_{2}{ }^{-}$according to Eqs. (1) and (2)

$$
\begin{aligned}
& \mathrm{NO}_{2}^{-}+\mathrm{H}_{2} \mathrm{O}_{2}+\mathrm{H}^{+} \rightarrow \mathrm{NO}_{3}^{-}+\mathrm{H}_{2} \mathrm{O}+\mathrm{H}^{+}, \\
& 3 \mathrm{~N}_{3}^{-}+\mathrm{NO}_{2}^{-}+4 \mathrm{H}^{+} \rightarrow 5 \mathrm{~N}_{2}+2 \mathrm{H}_{2} \mathrm{O},
\end{aligned}
$$

did not increase $\mathrm{H}_{2} \mathrm{O}_{2}$ deposition (data not shown). However, both reactions (1) and (2) could be competing reactions. In good agreement with Figs. 8(c) and 8(d), the role of hydrogen peroxide on cell viability is limited or absent in the case of argon RF plasma with air or oxygen admixture.

Griess assay showed the deposition of nitrite/nitrate depending on dose and distance in the case of argon or $\mathrm{Ar} /$ $\mathrm{H}_{2} \mathrm{O}$ plasma [Fig. 11(a)]. This is an expected result and correlates well with the known chemistry of jet based plasmas and their interaction with liquids. ${ }^{37,48}$ However, the impact of these nitrogen species on cell proliferation rate is limited. Sodium nitrite did not affect $\mathrm{HaCaT}$ cell proliferation rates up to $2000 \mu \mathrm{M}$ under test conditions [Fig. 12(a)]. In combination of $\mathrm{NaNO}_{2}(125 \mu \mathrm{M})$ with $\mathrm{H}_{2} \mathrm{O}_{2}$, the effect was solely determined by the $\mathrm{H}_{2} \mathrm{O}_{2}$ concentration [Fig. 12(b)]. 
TABLE I. Array of the tested scavengers and their effect on the cell proliferation rate.

\begin{tabular}{|c|c|c|c|c|c|c|c|c|}
\hline & $\mathrm{Fe}^{2+}$ & Catalase & SOD/catalase & Mannitol & Histidin & Ascorbic acid & Sodium pyruvate & GSH \\
\hline Argon & + & +++ & $+++^{\mathrm{a}}$ & - & nd & nd & ++ & + \\
\hline Humidified argon & + & +++ & $+++^{\mathrm{a}}$ & - & nd & nd & ++ & + \\
\hline Argon- $1 \% \mathrm{O}_{2}$ & - & - & - & - & ++ & ++ & - & nd \\
\hline Argon-1\% air & - & - & - & - & + & + & - & nd \\
\hline
\end{tabular}

${ }^{\mathrm{a}}$ Effect of catalase

Note: (ability to interfere with plasma impact on cell viability: +++ very strong, no observable effect of plasma treatment; ++ strong, observable effect clearly diminished; + weak, slight reduction of observable effect; - no effect, effectivity of plasma treatment not affected; and nd, not measured). Fe ${ }^{2+}$ is the iron ions, SOD is the superoxide dismutase, and GSH is the glutathione. Treatment conditions: RF jet with $2.5 \mathrm{~W}, 8 \mathrm{~mm}$ distance, $1.5 \mathrm{slm}$ argon w/or w/o admixture.

Interestingly, neither nitrite nor nitrate deposition could be measured by the Griess assay for the $\mathrm{Ar} / \mathrm{O}_{2}$ and $\mathrm{Ar} / \mathrm{air}$ condition. This is contradictory to the gas phase reactive species densities which indicate the presence of significant amounts of $\mathrm{NO}, \mathrm{NO}_{2}{ }^{-}$, and $\mathrm{NO}_{3}{ }^{-}$even if no nitrogen or air was admixed to the working gas [Figs. 9(c) and 9(d)]. An interpretation of this observation could be the impact of gas flow mechanics in confined spaces, which reduced the amount of surrounding air diffusing into the jet effluent zone, and had not been taken into account in the modeling approach. Another possible explanation could be the creation
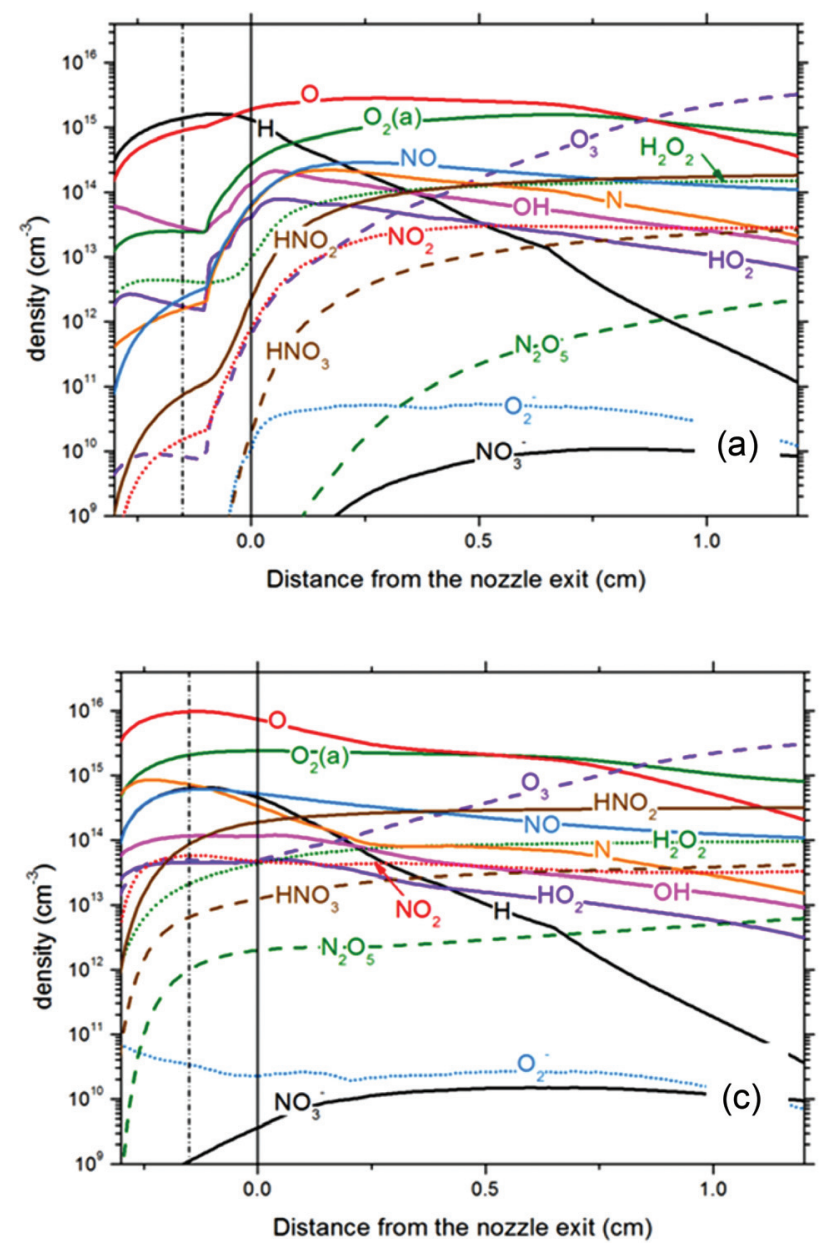

of peroxynitrite, which cannot be detected by the Griess assay. This RNS can be created by the following different chemical reactions: ${ }^{49}$

$$
\begin{aligned}
& \mathrm{O}_{2} \cdot{ }^{-}+\mathrm{NO} \rightarrow \mathrm{ONO}_{2}^{-} ; \mathrm{k}=3.8 \times 10^{9} \mathrm{M}^{-1} \mathrm{~s}^{-1}(p \mathrm{H} 7.5), \\
& \mathrm{NO}_{2}^{-}+\mathrm{H}_{2} \mathrm{O}_{2}+\mathrm{H}^{+} \rightarrow \mathrm{O}=\mathrm{NOOH}+\mathrm{H}_{2} \mathrm{O}
\end{aligned}
$$

The presence of superoxide would be mandatory for reaction (3). The use of superoxide dismutase to rescue cell viability after argon-oxygen RF jet treatment was not effective
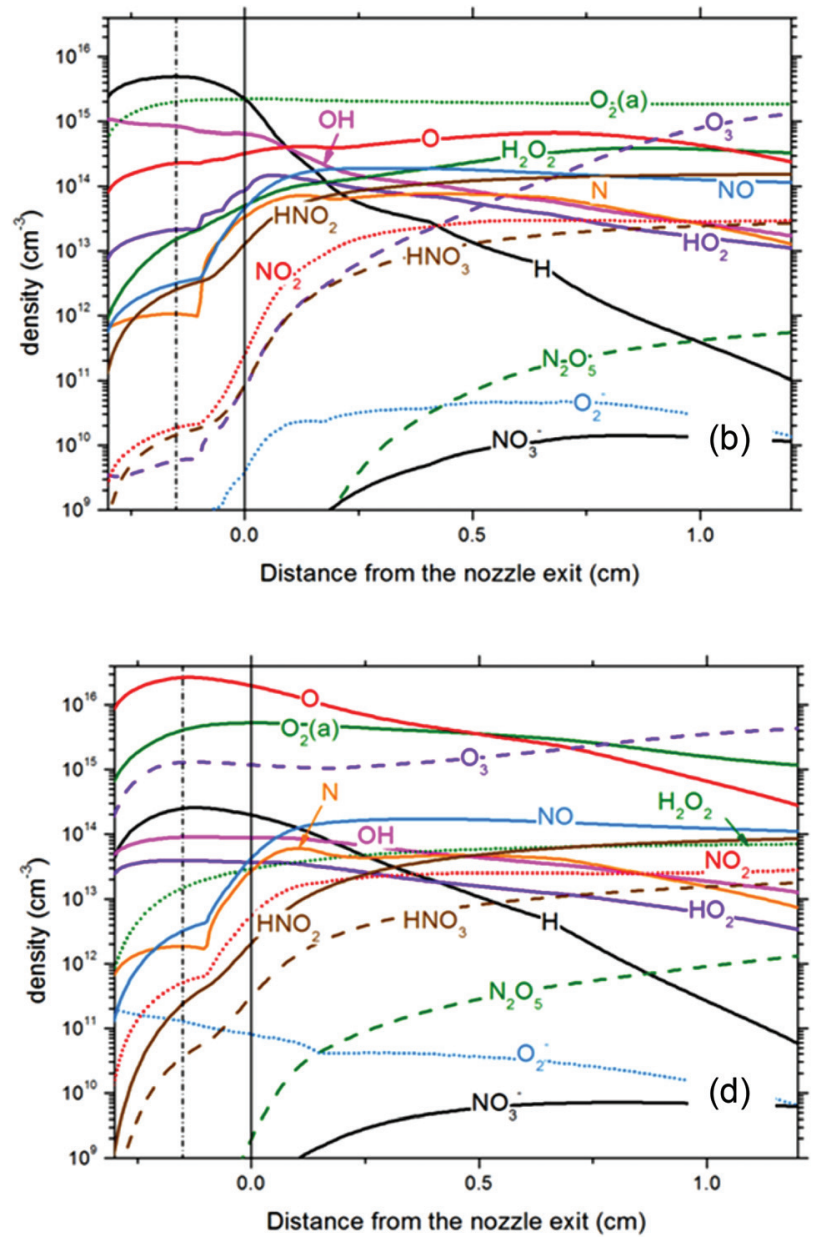

FIG. 9. Calculated densities of biologically relevant species in the plasma under four different plasma conditions as in Fig. 8. [(a): $\mathrm{Ar}$, (b): $\mathrm{Ar} / 0.27 \% \mathrm{H}{ }_{2} \mathrm{O}$, (c): $\mathrm{Ar} / 1 \%$ air, and $\left.(\mathrm{d}): \mathrm{Ar} / 1 \% \mathrm{O}_{2}\right]$. 

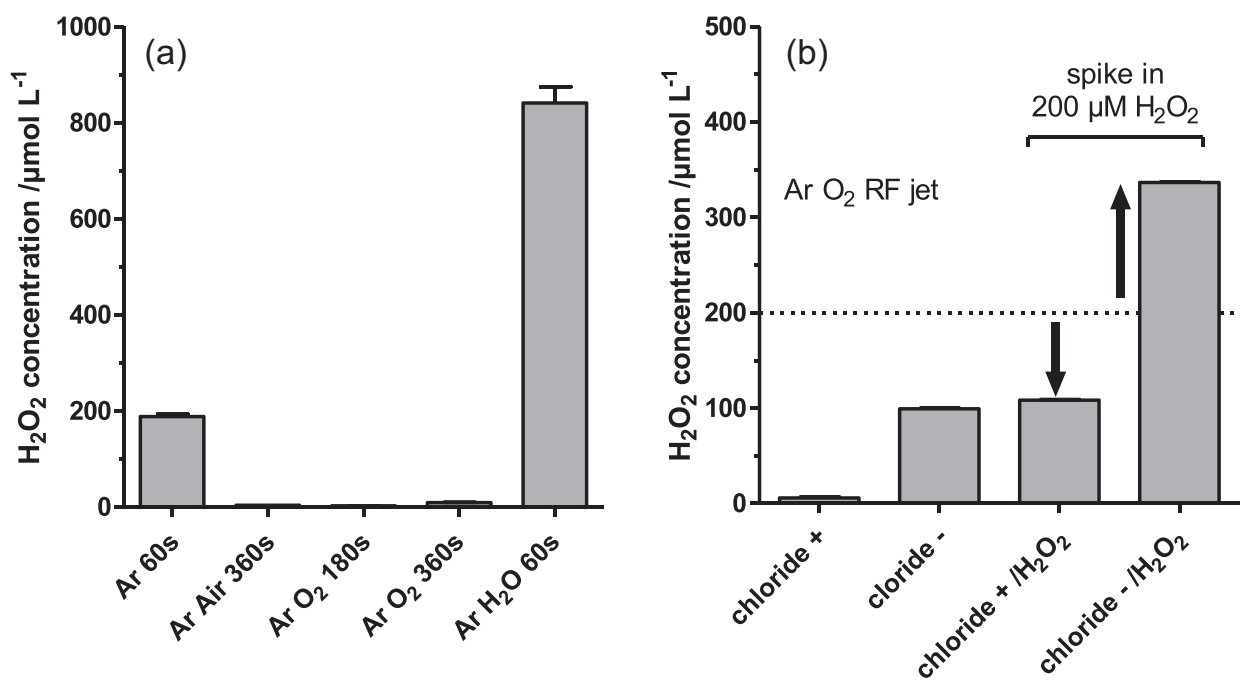

FIG. 10. (a) Hydrogen peroxide deposition by RF jet in PBS Glc buffer ( $8 \mathrm{~mm}$ distance) occurs only in $\mathrm{Ar}$ and $\mathrm{Ar} / \mathrm{H}_{2} \mathrm{O}$ plasma. No accumulation if $\mathrm{O}_{2}$ is present in working gas. (b) $\mathrm{Ar} / \mathrm{O}_{2}$ plasma treatment of (chloride free) nonionic buffer (chloride -) or PBS (chloride + ) with or without $\mathrm{H}_{2} \mathrm{O}_{2}$ spike in $(200 \mu \mathrm{M}$, dotted line) shows a depletion resp. a missing accumulation of $\mathrm{H}_{2} \mathrm{O}_{2}$ in the presence of chloride ions. If chloride is absent, $\mathrm{H}_{2} \mathrm{O}_{2}$ is deposited. $\mathrm{RF}$ jet $\mathrm{Ar} / 1 \% \mathrm{O} \mathrm{O}_{2}$ $40 \mathrm{~s}, 8 \mathrm{~mm}$ distance. Data represent mean and range; two independent experiments were performed. Error bars can be smaller than lines.

(see Table I). Also, the creation of superoxide from solvated electrons and dissolved oxygen in the buffer is unlikely since the amount of electrons and negative ions in the afterglow of the plasma in $\mathrm{Ar} / \mathrm{O}_{2}$ was very low (noncontact treatment conditions). According to reaction (4), an acidic environment is necessary to create peroxynitrous acid, which is not present in the physiologic buffer systems $(p \mathrm{H} \approx 7.4)$ and the reaction would be slow.

If formed, peroxynitrite is very reactive, is not stable under neutral $p \mathrm{H}$ conditions, and reacts with carbon dioxide yielding carbon centered radicals [Eq. (5)]. ${ }^{50}$

$$
\begin{gathered}
\mathrm{ONO}_{2}^{-}+\mathrm{CO}_{2} \rightarrow \cdot \mathrm{NO}_{2}+\cdot \mathrm{CO}_{3}^{-} \\
\mathrm{k}=4.6 \times 10^{4} \mathrm{M}^{-1} \mathrm{~s}^{-1}(p \mathrm{H} 7.4)
\end{gathered}
$$

This is a moderately fast reaction, which can easily occur in cell culture medium. However, Carballal et al. indicated the parallel creation of $\mathrm{NO}_{2}$ under these conditions [see Eq. (5)]. ${ }^{51}$ Being the anhydride of $\mathrm{HNO}_{3}$ it would be detectable by the Griess assay after reduction by $\mathrm{VCl}_{3}$.

The deposition of RNS is often accompanied by the creation of protons in the treated liquids. An acidic environment may have an impact on cell viability by itself. However, no changes in $p \mathrm{H}$ values were detected in $\mathrm{PBS}(p \mathrm{H}$ 7.46) even after 10 min treatment $(p \mathrm{H} 7.46)$ with argon $\mathrm{RF}$ jet, w/or w/o $1 \%$ oxygen. In contrast, using distilled $\mathrm{H}_{2} \mathrm{O}(p \mathrm{H}$ 5.91), a $p \mathrm{H}$ drop was measured $(p \mathrm{H}$ 3.80) under identical conditions. Accordingly, the RF plasma induces the creation of protons but these are scavenged by the buffer. We assume, therefore,
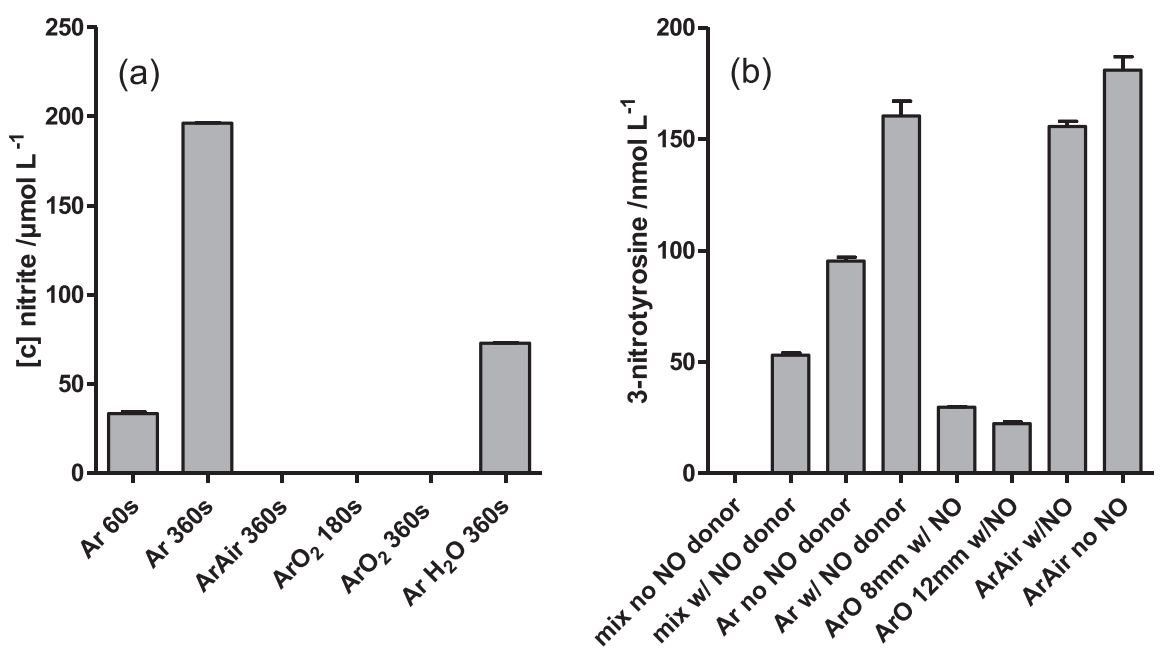

FIG. 11. (a) Nitrite generation by RF plasma (Griess assay). No nitrite/nitrate was detected after Ar/ $\mathrm{O}_{2}$ or Ar/air plasma (nitrate after reduction with acidic $\mathrm{VCl}_{3}$ ). (b) Generation of 3-nitrotyrosine from L-tyrosine indicate active peroxynitrite chemistry in case of Ar and Ar/air RF jet. Treatment at 8 or 12 mm distance, in phosphate buffer $p \mathrm{H} 7.3,600 \mathrm{~s}$ argon, $\mathrm{Ar} / \mathrm{O}_{2}$, Ar/air. w/NO = with NO donor (see text). Data represent mean/ $\pm \mathrm{SD}$ of two experiments with three replicates each. In some cases, error bars are smaller than lines. 

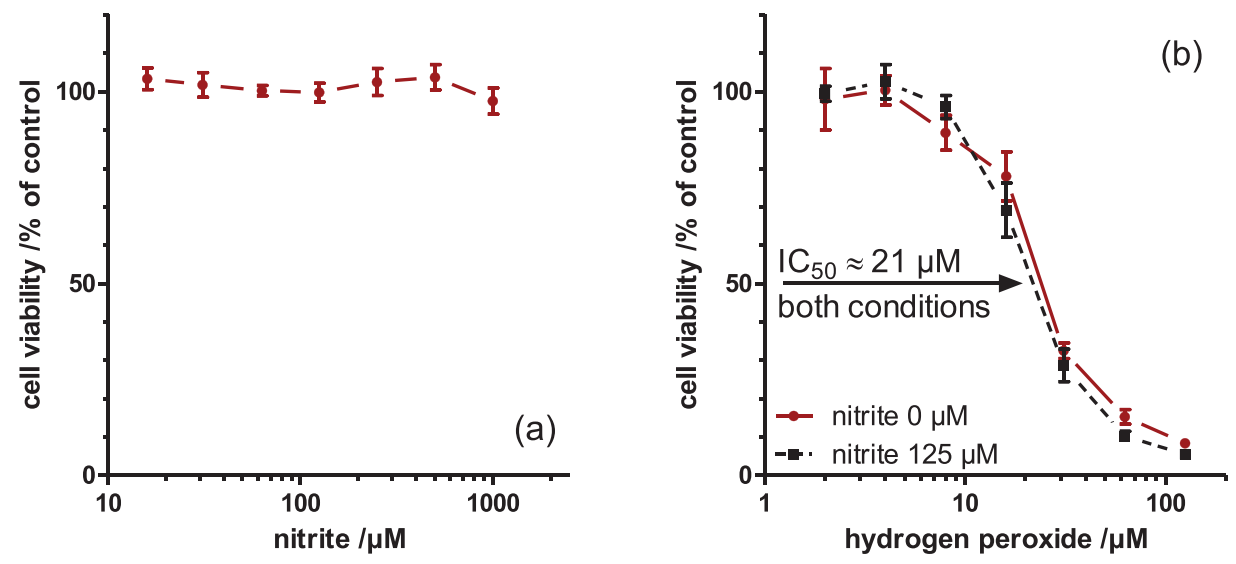

Fig. 12. (a) Nitrite does not interfere with cell proliferation (HaCaT). (b) Combination of nitrite $(125 \mu \mathrm{M})$ and $\mathrm{H}_{2} \mathrm{O}_{2}$ (varying concentrations). No additional effect of $\mathrm{NO}_{2}{ }^{-}$on $\mathrm{HaCaT}$ proliferation detected. $\mathrm{IC}_{50}$ of $\mathrm{H}_{2} \mathrm{O}_{2}$ and $\mathrm{NO}_{2}{ }^{-} / \mathrm{H}_{2} \mathrm{O}_{2}$ combination is identic $21 \mu \mathrm{M}$. Data represent mean/ $\pm \mathrm{SD}$ of three experiments with six replicates each.

that chemical reactions or biological effects under the experimental conditions are not induced by $p \mathrm{H}$ changes.

In an alternative approach, the presence of RNS (or superoxide) was investigated using tyrosine as a chemical sensor according to Sawa et $a l .{ }^{25}$ If either reactive species is created by the plasma treatment peroxynitrite can be formed in the liquid under specific experimental conditions. Its reaction with tyrosine would yield a nitrogen adduct (3-nitrosotyrosine, 3-nitrotyrosine) which could then be detected by UPLC/mass spectrometry. The optional presence of an NO donor (diethylamine NONOate) allows distinguishing between RNS plasma chemistry and ROS plasma chemistry. The results of this assay are shown in Fig. 11(b). Highest yields of 3-nitrotyrosine (3-NT) were detected for argon-air and pure argon RF plasmas, indicating the deposition of RNS by the plasma. An additional supplementation of a NO donor only increased 3-NT generation in the case of the pure argon RF plasma (Fig. 11, column Ar w/NO donor). Only small amounts of 3-NT could be measured for $\mathrm{Ar} / \mathrm{O}_{2} \mathrm{RF}$ plasma even in the presence of the $\mathrm{NO}$ donor (columns $\mathrm{ArO}$ $\mathrm{w} / \mathrm{NO}$ ) regardless of distance ( 8 or $12 \mathrm{~mm}$ ). This observation suggests that there is a role of RNS but it might be negligible under $\mathrm{Ar} / \mathrm{O}_{2}$ conditions and rather points at the presence of low amounts of ROS.

The data from Griess assay and from the tyrosine nitration assay show that RNS clearly plays a role in the case of pure argon RF jet and its humidified version as seen by nitrite deposition and 3-nitrotyrosine production. The role of RNS in the $\mathrm{Ar} /$ air and $\mathrm{Ar} / \mathrm{O}_{2} \mathrm{RF}$ plasma triggered chemistry is less obvious as seen by a negative Griess assay and discrepant 3-NT production. Yet unraveled mechanisms may interfere with RNS detection or speed their decomposition. Their role in the liquid chemistry hence remains to be specified and thoroughly investigated in future work.

\section{Time related effects of Argon-oxygen RF plasma}

Effect of delay (1-60 min) between plasma treatment and transfer of the liquid onto cells is shown in Fig. 13. With a distance of $12 \mathrm{~mm}$ between nozzle and liquid surface [Fig. 13(a)], the average cell viability was unaffected by treatment with Ar/air plasma $(360 \mathrm{~s}, \approx 95 \%$ residual cell viability) or $\mathrm{Ar} / \mathrm{O}_{2}$ plasma ( $360 \mathrm{~s}, \approx 92 \%$ residual cell viability). After argon RF plasma treatment (120s) a residual cell viability of about $58 \%$ remains throughout the observation period. This shows that active species generated by the argon plasma were stable for at least $60 \mathrm{~min}$. This is in good agreement with $\mathrm{H}_{2} \mathrm{O}_{2}$ centered chemistry as shown in Figs. 6(a), 6(b), 8(a), and 10(a). If the distance is reduced to $8 \mathrm{~mm}$, the observed biological impact increases [Fig. 13(b)].

Argon RF plasma treatment ( $60 \mathrm{~s}$ treatment) showed a residual average cell viability close to $30 \%$ throughout the observed time. A similar observation was made for $\mathrm{Ar} / \mathrm{H}_{2} \mathrm{O}$ plasma ( 30 s treatment, $\approx 20 \%$ cell viability). In both cases, the increased deposition of $\mathrm{H}_{2} \mathrm{O}_{2}$ with reduced distance between nozzle and liquid explains the observation [Fig. 6(a)]. When using Ar/air RF plasma jet no effect on cell viability was detected even after 360 s treatment $(\approx 95 \%$ residual cell viability, no effect of delay time). In contrast to all three cases, there is a strong dependence of the biological effect on delay time in the case of $\mathrm{Ar} / \mathrm{O}_{2}$ plasma (180 s treatment). A very profound impact on CRFK viability was detected if buffer was added immediately to the cells $(0 \mathrm{~min}$ delay). This impact degrades with increasing delay time between treatment and addition to the cells: after $60 \mathrm{~min}$ delay, no effect on cell viability could be detected. The halflife time of this effect was approximately $30 \mathrm{~min}$. In contrast, $\mathrm{H}_{2} \mathrm{O}_{2}$ is stable under the experimental conditions for at least $60 \mathrm{~min}$ (in treatment buffer, a 3.5\% decay of plasma $\mathrm{H}_{2} \mathrm{O}_{2}$ was observed within $90 \mathrm{~min}$ ). Concentrations $<500 \mu \mathrm{M}$ markedly reduce the cell proliferation rate by inducing a cell cycle block but do not lead to necrosis and total loss of cell viability within the $1 \mathrm{~h}$ incubation according the experimental procedure (Fig. 4). Hence, even after long RF argon plasma treatment ( $>1000 \mathrm{U}$ ), inducing $\mathrm{H}_{2} \mathrm{O}_{2}$ chemistry, a residual cellular metabolism is detectable (Fig. 4). As this is not the case for $\mathrm{Ar} / \mathrm{O}_{2} \mathrm{RF}$ plasma [Fig. 13(b)], this treatment creates a different chemistry. 

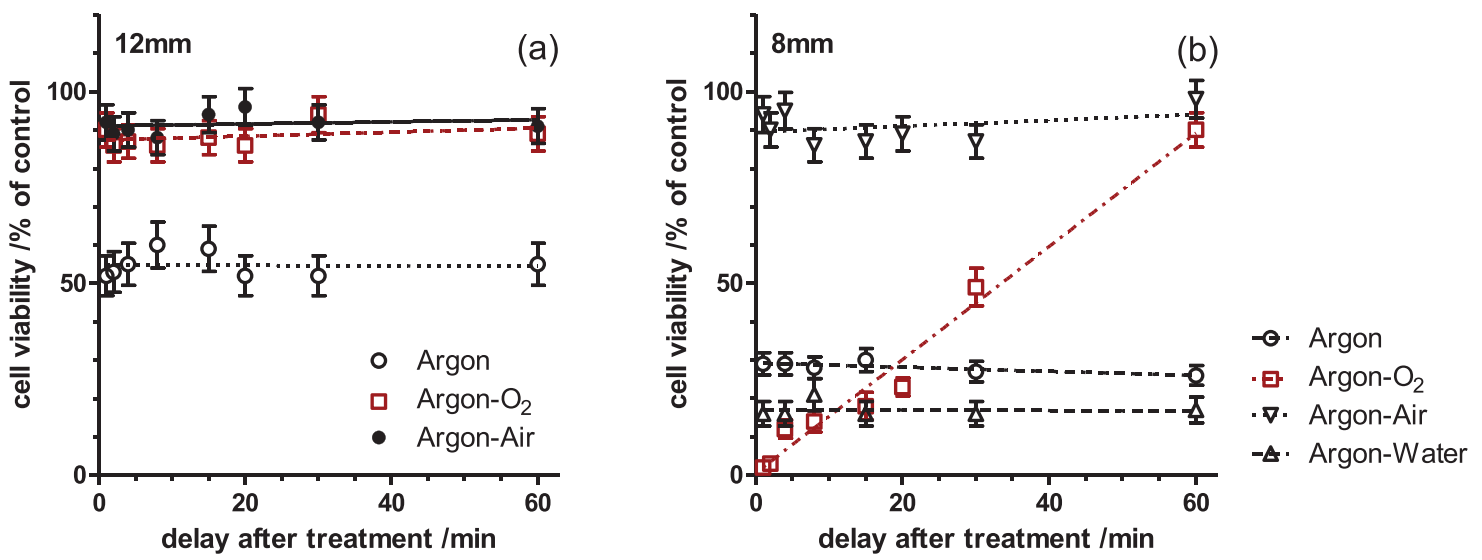

FIG. 13. Time delay between $\mathrm{Ar} / \mathrm{O}_{2} \mathrm{RF}$ plasma treatment and transfer of the liquid onto cells significantly affects cell viability at a distance of $8 \mathrm{~mm}[(\mathrm{~b})$, red curve)]. For $12 \mathrm{~mm}$, this was not observed [(a), red curve). Ar, Ar/water, and Ar/air RF plasma did not show a similar behavior [(a) and (b), black curves]. Each point consists of the average of three experiments and three replicates. Data represent mean/ \pm SD.

To facilitate identification, the reactive species created by the RF plasma variants, different scavengers have been added to the treatment buffer (PBS $+1 \mathrm{~g} / \mathrm{l}$ glucose). The results are summarized in Table I. Neither catalase nor the small molecule $\mathrm{H}_{2} \mathrm{O}_{2}$ scavenger sodium pyruvate did attenuate cell viability reduction triggered by argon-air or argo$\mathrm{n}$-oxygen RF plasma, but both were effective in the argon and argon-water case. This is in agreement with the chemical detection of the $\mathrm{H}_{2} \mathrm{O}_{2}$ presence [Fig. 10(a)]. Catalase reacts in an enzymatic reaction with $\mathrm{H}_{2} \mathrm{O}_{2}$. The reaction is very fast $\left(2 \times 10^{-7} \mathrm{M}^{-1} \mathrm{~s}^{-1}\right)$, yielding oxygen and water. ${ }^{52}$ Pyruvate nonenzymatically reacts with $\mathrm{H}_{2} \mathrm{O}_{2}$, creating $\mathrm{CO}_{2}$, acetic acid, and water ${ }^{53}$

$$
\mathrm{CH}_{3} \mathrm{COCOO}^{-}+\mathrm{H}_{2} \mathrm{O}_{2} \rightarrow \mathrm{CO}_{2}+\mathrm{CH}_{3} \mathrm{COO}^{-}+\mathrm{H}_{2} \mathrm{O} \text {. }
$$

The scavenging effect of peroxynitrite with pyruvate has also been proposed $\left(\mathrm{k}=88 \mathrm{M}^{-1} \mathrm{~s}^{-1}\right.$ at $p \mathrm{H}$ 7.4).$^{54}$ No effect on cell viability was found upon the addition of SOD and SOD-catalase mixture in the case of argon-oxygen RF plasma. This seems to indicate that the effect on cell viability is not dominated by $\mathrm{O}_{2}^{-}$, an observation also supported by the small amounts of 3-nitrotyrosine (3-NT) detected in the tyrosine nitration assay [Fig. 11(a)]. The detection of tyrosine nitration in the presence of a NO donor would be an indicator for superoxide. In contrast, L-histidine and L-ascorbic acid showed a dose dependent reduction of the plasmas' biological impact but without a complete rescue. Longer treatments $(>300 \mathrm{U})$ could not be compensated by $3 \mathrm{mM}$ scavenger. L-histidine is a scavenger for singlet oxygen, ${ }^{55}$ and L-ascorbic acid scavenges among other ROS/RNS also peroxynitrite. ${ }^{56}$

Concluding from the above scavenger study, ozone, singlet oxygen, or atomic oxygen might be the active species or the precursors of the species, which cause the cell viability reduction in the case of argon-oxygen RF plasma. The lifetime of singlet oxygen [ 10s (Ref. 57)] and atomic O (likely $\sim 10 \mu \mathrm{s}$ ) would suggest that $\mathrm{O}_{3}$ is the dominant mechanisms (with a typical lifetime of $10 \mathrm{~min}$ in water at room temperature and $p \mathrm{H}$ 7). ${ }^{58}$ However, ozone would not lead to the observed distance effect because its stability is high enough to survive the increased travel time, and hence, according to the simulation, its amount remains unchanged throughout the considered distance from the nozzle [Fig. 9(d)]. Also, the kinpen ${ }^{58}$ produces a comparable amount of ozone as the RF jet ${ }^{23}$ but did not create a similar time and distance dependent biological impact. A similar argument can be made for singlet oxygen as its concentration in the effluent remains constant [see Fig. 9(d)]. Atomic oxygen is the only neutral species that seems to have significant distance dependence in the effluent (Fig. 9). This is consistent with the distance dependent effect observed in the cell proliferation study (Fig. 6). Secondary chemistry induced by $O$ in the liquid phase with a longer lifetime seems to be responsible for the effect. Unfortunately, the $\mathrm{O}$ chemistry in liquids is not studied in detail and actually only recently gained interest in the biological community. ${ }^{59}$

To check the hypothesis of atomic oxygen induced chemistry, we investigated the decomposition of $\mathrm{H}_{2} \mathrm{O}_{2}$ by the plasma treatment (Fig. 14). Under some conditions, $\mathrm{H}_{2} \mathrm{O}_{2}$ reacts quickly with atomic oxygen $\left(1.6 \times 10^{9} \mathrm{M}^{-1} \mathrm{~s}^{-1}\right.$, $p \mathrm{H}>8.7)$ but much slower with ozone $\mathrm{O}_{3}\left(0.065 \mathrm{M}^{-1} \mathrm{~s}^{-1}\right){ }^{60}$ Indeed, a reduction of the $\mathrm{H}_{2} \mathrm{O}_{2}$ concentration was found for $8 \mathrm{~mm}$, while this was not the case for $14 \mathrm{~mm}$ [Fig. 13(a)], indicating that the $\mathrm{O}$ chemistry might indeed be important for the distance effects observed in the argon-oxygen RF plasma jet.

The $\mathrm{O}$ chemistry could lead by reaction with dissolved $\mathrm{O}_{2}$ in the liquid phase to form $\mathrm{O}_{3}$ and in principle induce the same chemistry as $\mathrm{O}_{3} .{ }^{61}$ Nonetheless, we found that the presence of chloride ions $\left(\mathrm{Cl}^{-}\right)$is critical to obtain the depletion in $\mathrm{H}_{2} \mathrm{O}_{2}$ concentration [Fig. 13(b)]. We believe that this could be due to the known effect of scavenging of active chlorine compounds by $\mathrm{H}_{2} \mathrm{O}_{2}{ }^{62}$

The following reaction mechanism is proposed:

$$
\mathrm{Cl}^{-}+\mathrm{O} \rightarrow \mathrm{OCl}^{-} \text {. }
$$

However, to the authors' knowledge, reaction rates of this reaction are not reported in literature. It is similar to ${ }^{63}$ 

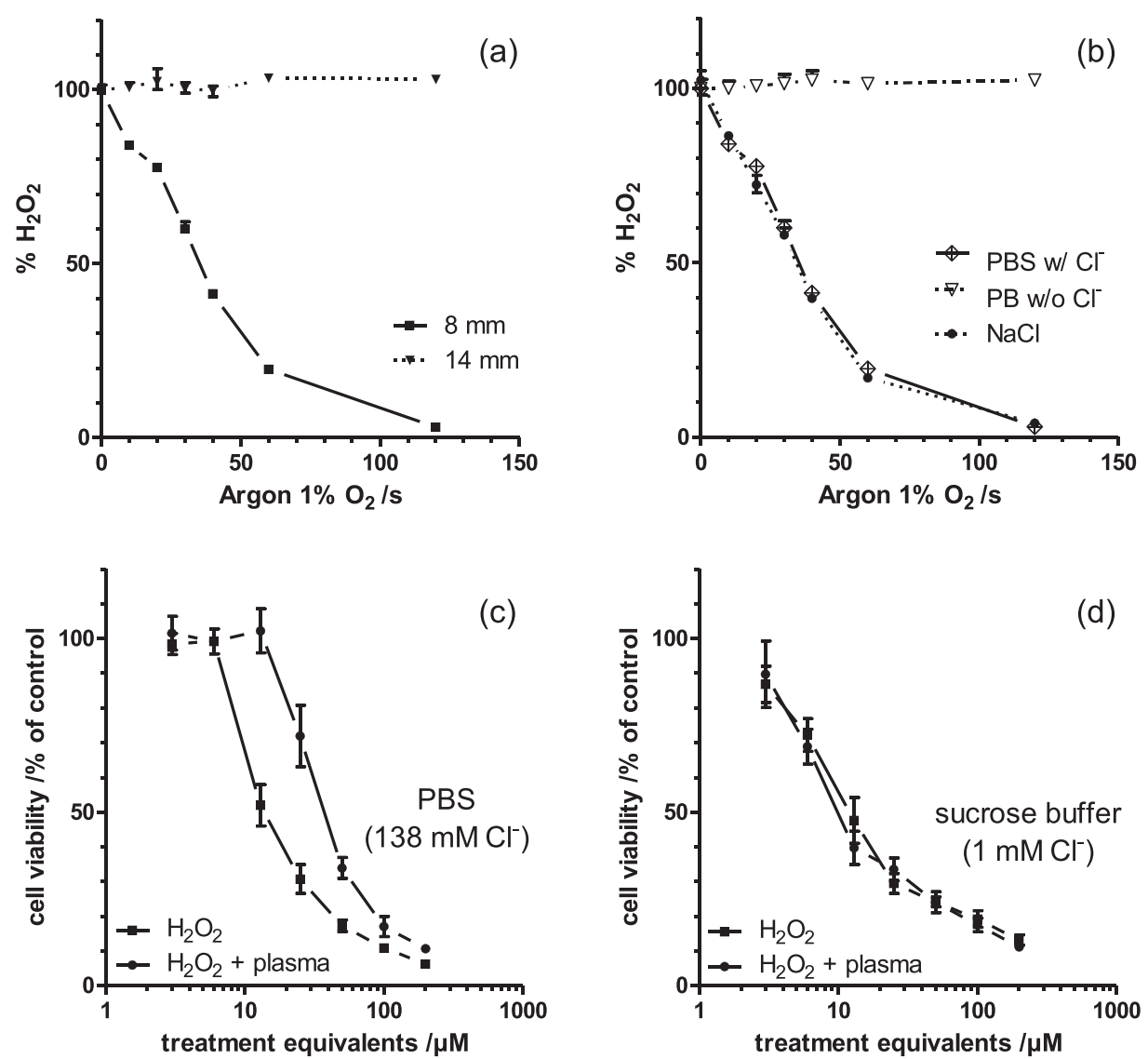

FIG. 14. (a) Impact of distance on hydrogen peroxide decomposition by $\mathrm{Ar} / \mathrm{O}_{2} \mathrm{RF}$ plasma treatment ( 8 or $14 \mathrm{~mm}$ ) in $\mathrm{PBS}$. (b) Presence of $\mathrm{Cl}^{-}$is mandatory for $\mathrm{H}_{2} \mathrm{O}_{2}$ decomposition (phosphate buffer systems, $10 \mathrm{mM}$, and $p \mathrm{H}$ 7.4). [(c) and (d)] Biological impact of $200 \mu \mathrm{M} \mathrm{H}_{2} \mathrm{O}_{2}$ treated with $\mathrm{Ar} / \mathrm{O}_{2} \mathrm{RF}$ jet (40 s, $8 \mathrm{~mm}$ ). If $\mathrm{Cl}^{-}$is present, the treated solution is less effective than untreated (c), and if $\mathrm{Cl}^{-}$is (almost) absent, plasma treatment did not change impact on cell viability (d). $w / \mathrm{Cl}^{-}=$with chloride ions present, w/o $\mathrm{Cl}^{-}$chloride ions absent. Data represent mean/ $\pm \mathrm{SD}$ of two [(a) and (b)] or three [(c) and (d)] experiments with three $[(a)$ and (b)] or six [(c) and (d)] replicates each.

$$
\mathrm{Cl}^{-}+\cdot \mathrm{OH} \rightarrow \mathrm{HClO}^{-} ; \mathrm{k}=3 \times 10^{9} \mathrm{M}^{-1} \mathrm{~s}^{-1},
$$

which is a very fast reaction and an equivalent reaction is proposed in biology. ${ }^{64}$

The $\mathrm{ClO}^{-}$will react with $\mathrm{H}_{2} \mathrm{O}_{2}$ forming $\mathrm{Cl}^{-}, \mathrm{O}_{2}$, and $\mathrm{H}_{2} \mathrm{O}$, as is as a standard performed as a dechlorination process [Eq. (9)] (Refs. 65 and 66)

$$
\begin{gathered}
\mathrm{OCl}^{-}+\mathrm{H}_{2} \mathrm{O}_{2} \rightarrow \mathrm{Cl}^{-}+\mathrm{H}_{2} \mathrm{O}+\mathrm{O}_{2}, \\
\mathrm{H}^{+}+\mathrm{ClO}^{-} \leftrightarrow \mathrm{HOCl} ; \quad \mathrm{pKa}=7.8 .
\end{gathered}
$$

$\mathrm{ClO}^{-}$, being in equilibrium with its corresponding acid [Eq. (10)] has a strong impact on cell viability if present ( $>10 \mu \mathrm{M}$, Fig. 4). As indicated by the decomposition of $200 \mu \mathrm{M} \mathrm{H}_{2} \mathrm{O}_{2}$ within $100 \mathrm{~s}$ plasma treatment, these concentrations can be easily reached [Fig. 13(b)]. Hypochlorite is a strong oxidant and has intense antimicrobial properties but holds no genotoxic potential. ${ }^{67}$ In humans, it plays an important role in unspecific immunity as the product of the enzyme myeloperoxidase, which is found in neutrophils. ${ }^{68}$

Alternatively, the following reaction could be responsible for the decay of $\mathrm{H}_{2} \mathrm{O}_{2}$ in the presence of $\mathrm{Cl}^{-}:$:62,69

$$
. \mathrm{Cl}_{2}^{-}+\mathrm{H}_{2} \mathrm{O}_{2} \rightarrow \text { products; } \mathrm{k}=4.1 \times 10^{4} \mathrm{M}^{-1} \mathrm{~s}^{-1} .
$$

However, there are two constraints for this reaction: the $p \mathrm{H}$ needs to be low (around $p \mathrm{H} \mathrm{1}$ ) and $\mathrm{Cl}_{2}{ }^{-}$needs to be created first. The $p \mathrm{H}$ in our reaction is around 7.4 and is not changed by the treatment $\left(\Delta p \mathrm{H} 0.0 / 5\right.$ min treatment, $\mathrm{Ar} / \mathrm{O}_{2} \mathrm{RF}$ jet, $8 \mathrm{~mm}$ distance, and $3 \mathrm{ml} \mathrm{PBS}$ ) although using natural saline where the $p \mathrm{H}$ is dropping by the treatment $(\Delta p \mathrm{H} 1.61 / 5 \mathrm{~min}$ treatment, $\mathrm{Ar} / \mathrm{O}_{2} \mathrm{RF}$ jet, $8 \mathrm{~mm}$ distance, and $3 \mathrm{ml} 0.9 \%$ sodium chloride solution) an identical $\mathrm{H}_{2} \mathrm{O}_{2}$ decay was observed [Fig. 14(b)]. The other constraint would be the creation of $\mathrm{Cl}_{2}^{-}$, which could be achieved by the following reactions: ${ }^{63,70}$

$$
\begin{aligned}
& \mathrm{HClO}^{-}+\mathrm{Cl}^{-} \rightarrow \mathrm{HO}^{-}+\cdot \mathrm{Cl}_{2}^{-} ; \mathrm{k}=1 \times 10^{4} \mathrm{M}^{-1} \mathrm{~s}^{-1}, \\
& \mathrm{Cl}^{-}+\cdot \mathrm{Cl} \rightarrow \cdot \mathrm{Cl}_{2}^{-} ; \quad \mathrm{k}=8 \times 10^{9} \mathrm{M}^{-1} \mathrm{~s}^{-1} .
\end{aligned}
$$

Both reactions (12) and (13) rely on the creation of either $\cdot \mathrm{Cl}$ or $\mathrm{HClO}^{-}$. Due to the transient nature of these radicals, only limited research has been made in aqueous systems. Possible reactions are all based on radical mechanisms, either phosphate, sulfur, or nitrogen centered. ${ }^{71}$ However, the decay of $\mathrm{H}_{2} \mathrm{O}_{2}$ by $\mathrm{Ar} / \mathrm{O}_{2}$ RF plasma takes place also in the absence of phosphate or sulfate, indicating that these species are not mandatory. Hence, the reaction involving nitrogen might be the most relevant. In contradiction, the Griess assay was not 
able to detect the deposition of $\mathrm{NO}_{2}{ }^{-} / \mathrm{NO}_{3}{ }^{-}$[Fig. 11(a)] after treatment with $\mathrm{Ar} / \mathrm{air}$ or $\mathrm{Ar} / \mathrm{O}_{2}$ plasma. This observation highlights again a possible role of RNS, which have not yet been thoroughly understood.

In Figs. 14(c) and 14(d), the residual impact of a hydrogen peroxide solution in physiological buffer (138 vs $1 \mathrm{mM}$ chloride) on mammalian cells after $\mathrm{Ar} / \mathrm{O}_{2} \mathrm{RF}$ jet treatment is shown. A significant difference between treated (apparent $\left.\mathrm{IC}_{50}=33 \mu \mathrm{M}\right)$ and untreated $\mathrm{PBS}-\mathrm{H}_{2} \mathrm{O}_{2}$ solution $\left(\mathrm{IC}_{50}\right.$ $=15.5 \mu \mathrm{M})$ was detected [Fig. 14(c)]. This difference is attributed to the reduction of $\mathrm{H}_{2} \mathrm{O}_{2}$ in the solution according to Eqs. (9) and (11). In contrast, no such effect could be detected when the chloride depleted sucrose buffer is used [Fig. 14(d)]. Apparent and authentic IC $_{50}$ are almost identical (16.8 vs $15.5 \mu \mathrm{M})$. This conclusion is further supported by using a chemical quantification of $\mathrm{H}_{2} \mathrm{O}_{2}$ [Fig. 10(b)]. Hydrogen peroxide accumulation is only seen when chloride ions are (almost) absent (chloride -). In high chloride conditions (chloride + ), roughly $100 \mu \mathrm{M}$ of $\mathrm{H}_{2} \mathrm{O}_{2}$ are consumed within $40 \mathrm{~s}$ of $\mathrm{Ar} / \mathrm{O}_{2}$ treatment, which is then reflected in the increase of the apparent $\mathrm{IC}_{50}$. These observations proof the assumed reaction (7) yielding $\mathrm{OCl}^{-}$under $\mathrm{Ar} / \mathrm{O}_{2} \mathrm{RF}$ treatment and underline the modifying role of chloride ions in plasma liquid chemistry.

$\mathrm{ClO}^{-}$is thermodynamically instable and it is in equilibrium with $\mathrm{Cl}_{2}$ through

$$
2 \mathrm{H}^{+}+\mathrm{ClO}^{-}+\mathrm{Cl}^{-} \leftrightarrow \mathrm{Cl}_{2}+\mathrm{H}_{2} \mathrm{O} .
$$

The formed chlorine gas can be released from solution which could account for the limited lifetime of a $\mathrm{RF} \mathrm{Ar} / \mathrm{O}_{2}$ plasma treated solution in terms of biological impact [Fig. 13(b)]. The presence of other RNS and ROS could enhance this effect. A similar observation has not been made for the kinpen due to the lower $\mathrm{O}$ density produced. ${ }^{72}$ The lower density is most likely due to the fact that the kinpen does not operate in $\mathrm{RF}$ mode $(13.7 \mathrm{MHz})$ but at lower frequency (around $1 \mathrm{MHz}$ ). Transitions from typical DBD modes (Townsend discharge, glow discharge) to RF modes have been found by Massines et al. at $1.3 \mathrm{MHz}$ in parallel plate geometries consistent with such a finding. ${ }^{73}$

\section{CONCLUSIONS}

An RF plasma jet operating with four different working gases (argon, argon/water, argon/air, and argon/oxygen) was investigated with respect to its biological impact, its distance dependency and the effect of time between plasma-liquid and liquid-cell contact. We found remarkable differences in the magnitude of the biological impact: Ar/water $\gg$ $\mathrm{Ar}>\mathrm{Ar} / \mathrm{O}_{2}>\mathrm{Ar} /$ air plasma (distance nozzle-liquid $12 \mathrm{~mm}$, no time delay after plasma treatment). In this case, effects could be attributed to hydrogen peroxide. However, if the distance was reduced to $8 \mathrm{~mm}, \mathrm{Ar} / \mathrm{O}_{2} \mathrm{RF}$ plasma showed a massive impact on cell proliferation. This distance dependent effect wore off with increasing delay time between treatment of the liquid and its cell contact. Using modeling data, chemical detection, comparison with the kinpen, and literature, we propose that in case of $\mathrm{Ar} / \mathrm{O}_{2} \mathrm{RF}$ plasma, hydrogen peroxide plays no prominent role when standard physiologic buffer or body fluids are treated; instead, the plasma chemistry is driven by atomic oxygen. Via reaction with chloride yielding $\mathrm{Cl}_{2}{ }^{-}$or $\mathrm{ClO}^{-}$, any hydrogen peroxide produced by the plasma itself is decomposed. These chlorine species have a limited lifetime under physiologic conditions and therefore show a strong time dependent biological activity. They interact with biological macromolecules, show an antimicrobial effect, and could hence be attributed to be responsible for the strong effects of oxygen admixtures in the biological impact of many nonthermal atmospheric pressure plasma sources. In addition, the results show clear differences in the biological action between two seemingly similar plasma jets, i.e., RF plasma jet and kinpen, which is attributed to strong differences in reactive species densities and different geometries. Hence, a distance dependency of species concentrations occurs in the RF jet, which is not found in the kinpen. While the importance of RNS for certain plasma conditions has been shown, the detailed chemical mechanism remains unclear.

\section{ACKNOWLEDGMENTS}

This work was founded, in part, by the German Federal Ministry of Education and Research (Grant No. 03Z2DN11), the Department of Energy Plasma Science Center through the U.S. Department of Energy, office of Fusion Energy Sciences (Contract No. DE-SC0001939), the University of Minnesota and the Institute for the Promotion of Innovation by Science and Technology in Flanders (IWT Flanders). W.V.G. and A.B. thank Mark Kushner (University of Michigan) for providing the numerical code.

${ }^{1}$ X. Lu, M. Laroussi, and V. Puech, Plasma Sources Sci. Technol. 21, 034005 (2012)

${ }^{2}$ T. von Woedtke, H. R. Metelmann, and K. D. Weltmann, Contrib. Plasma Phys. 54, 104 (2014).

${ }^{3}$ E. M. Liston, L. Martinu, and M. R. Wertheimer, J. Adhes. Sci. Technol. 7, 1091 (1993).

${ }^{4}$ J. Ehlbeck, U. Schnabel, M. Polak, J. Winter, T. von Woedtke, R. Brandenburg, T. von dem Hagen, and K. D. Weltmann, J. Phys. D: Appl. Phys. 44, 013002 (2011)

${ }^{5}$ S. Perni, G. Shama, and M. G. Kong, J. Food Prot. 71, 1619 (2008).

${ }^{6}$ O. Schluter, J. Ehlbeck, C. Hertel, M. Habermeyer, A. Roth, K. H. Engel, T. Holzhauser, D. Knorr, and G. Eisenbrand, Mol. Nutr. Food Res. 57, 920 (2013).

${ }^{7}$ D. B. Graves, J. Phys. D: Appl. Phys. 45, 263001 (2012).

${ }^{8}$ P. Bruggeman and R. Brandenburg, J. Phys. D: Appl. Phys. 46, 464001 (2013).

${ }^{9}$ J. Winter, K. Wende, K. Masur, S. Iseni, M. Dunnbier, M. U. Hammer, H. Tresp, K. D. Weltmann, and S. Reuter, J. Phys. D: Appl. Phys. 46, 295401 (2013).

${ }^{10}$ J. Waskoenig, K. Niemi, N. Knake, L. M. Graham, S. Reuter, V. Schulzvon der Gathen, and T. Gans, Plasma Sources Sci. Technol. 19, 045018 (2010).

${ }^{11}$ S. Hofmann, A. F. H. van Gessel, T. Verreycken, and P. Bruggeman, Plasma Sources Sci. Technol. 20, 065010 (2011).

${ }^{12}$ S. Samukawa et al., J. Phys. D: Appl. Phys. 45, 253001 (2012).

${ }^{13}$ S. A. Norberg, W. Tian, E. Johnsen, and M. J. Kushner, J. Phys. D: Appl. Phys. 47, 475203 (2014)

${ }^{14}$ D. Ellerweg, J. Benedikt, A. v. Keudell, N. Knake, and V. S.-v. d. Gathen, New J. Phys. 12, 013021 (2010). 
${ }^{15}$ A. Van Gessel, K. Alards, and P. Bruggeman, J. Phys. D: Appl. Phys. 46, 265202 (2013).

${ }^{16}$ J. Winter et al., J. Phys. D: Appl. Phys. 47, 285401 (2014).

${ }^{17}$ M. J. Pavlovich, H. W. Chang, Y. Sakiyama, D. S. Clark, and D. B. Graves, J. Phys. D: Appl. Phys. 46, 145202 (2013).

${ }^{18}$ J. L. Brisset and E. Hnatiuc, Plasma Chem. Plasma Process. 32, 655 (2012).

${ }^{19}$ S. Ikawa, K. Kitano, and S. Hamaguchi, Plasma Processes Polym. 7, 33 (2010).

${ }^{20}$ H. Y. Wu et al., Plasma Processes Polym. 9, 417 (2012).

${ }^{21}$ K. Wende, S. Reuter, T. von Woedtke, K. D. Weltmann, and K. Masur, Plasma Processes Polym. 11, 655 (2014).

${ }^{22}$ K. D. Weltmann, E. Kindel, R. Brandenburg, C. Meyer, R. Bussiahn, C. Wilke, and T. von Woedtke, Contrib. Plasma Phys. 49, 631 (2009).

${ }^{23}$ S. Q. Zhang, W. Van Gaens, B. van Gessel, S. Hofmann, E. van Veldhuizen, A. Bogaerts, and P. Bruggeman, J. Phys. D: Appl. Phys. 46, 205202 (2013).

${ }^{24}$ A. Schmidt-Bleker, S. Reuter, and K. Weltmann, J. Phys. D: Appl. Phys. 48, 175202 (2015).

${ }^{25}$ T. Sawa, T. Akaike, and H. Maeda, J. Biol. Chem. 275, 32467 (2000).

${ }^{26}$ M. J. Kushner, J. Phys. D: Appl. Phys. 38, 1633 (2005).

${ }^{27}$ W. V. Gaens, P. J. Bruggeman, and A. Bogaerts, New J. Phys. 16, 063054 (2014).

${ }^{28}$ W. V. Gaens and A. Bogaerts, J. Phys. D: Appl. Phys. 46, 275201 (2013).

${ }^{29}$ B. T. J. v. Ham, S. Hofmann, R. Brandenburg, and P. J. Bruggeman, J. Phys. D: Appl. Phys. 47, 224013 (2014).

${ }^{30}$ B. van Gessel, R. Brandenburg, and P. Bruggeman, Appl. Phys. Lett. 103, 064103 (2013).

${ }^{31}$ R. Brandenburg, H. Lange, T. von Woedtke, M. Stieber, E. Kindel, J. Ehlbeck, and K. D. Weltmann, IEEE Trans. Plasma Sci. 37, 877 (2009).

${ }^{32}$ L. Jakob, T. M. Hashem, S. Burki, N. M. Guindy, and A. M. Braun, J. Photochem. Photobiol., A 75, 97 (1993).

${ }^{33}$ J. Rozema et al., J. Photochem. Photobiol., B 66, 2 (2002).

${ }^{34}$ K. A. Franklin, V. S. Larner, and G. C. Whitelam, Int. J. Dev. Biol. 49, 653 (2005).

${ }^{35}$ A. Svobodova, D. Walterova, and J. Vostalova, Biomed. Pap. Med. Fac. Univ. Palacki., Olomouc., Czech. 150, 25 (2006).

${ }^{36}$ M. J. Pavlovich, Y. Sakiyama, D. S. Clark, and D. B. Graves, Plasma Processes Polym. 10, 1051 (2013).

${ }^{37}$ C. A. J. van Gils, S. Hofmann, B. K. H. L. Boekema, R. Brandenburg, and P. J. Bruggeman, J. Phys. D: Appl. Phys. 46, 175203 (2013).

${ }^{38}$ S. Bekeschus, J. Kolata, C. Winterbourn, A. Kramer, R. Turner, K. D. Weltmann, B. Broker, and K. Masur, Free Radical Res. 48, 542 (2014).

${ }^{39}$ A. Schmidt, K. Wende, S. Bekeschus, L. Bundscherer, A. Barton, K. Ottmuller, K. D. Weltmann, and K. Masur, Free Radical Res. 47, 577 (2013).

${ }^{40}$ S. Kalghatgi, C. M. Kelly, E. Cerchar, B. Torabi, O. Alekseev, A. Fridman, G. Friedman, and J. Azizkhan-Clifford, PLoS One 6, e16270 (2011).

${ }^{41}$ P. Lukes, E. Dolezalova, I. Sisrova, and M. Clupek, Plasma Sources Sci. Technol. 23, 015019 (2014).

${ }^{42}$ J. Nordberg and E. S. Arner, Free Radical Biol. Med. 31, 1287 (2001).

${ }^{43}$ R. A. Crandell, C. G. Fabrican, and W. A. Nelsonre, In Vitro-J. Tissue Cult. Assoc. 9, 176 (1973).
${ }^{44}$ P. Boukamp, R. T. Petrussevska, D. Breitkreutz, J. Hornung, A. Markham, and N. E. Fusenig, J. Cell Biol. 106, 761 (1988).

${ }^{45}$ K. Wende, S. Strassenburg, B. Haertel, M. Harms, S. Holtz, A. Barton, K. Masur, T. von Woedtke, and U. Lindequist, Cell Biol. Int. 38, 412 (2014).

${ }^{46}$ H. Tresp, M. U. Hammer, J. Winter, K. Weltmann, and S. Reuter, J. Phys. D.: App. Phys. 46, 435401 (2013).

${ }^{47}$ M. Dünnbier, A. Schmidt-Bleker, J. Winter, M. Wolfram, R. Hippler, K. Weltmann, and S. Reuter, J. Phys. D: Appl. Phys. 46, 435203 (2013).

${ }^{48}$ S. Reuter, H. Tresp, K. Wende, M. U. Hammer, J. Winter, K. Masur, A. Schmidt-Bleker, and K. Weltmann, IEEE Trans. Plasma Sci. 40, 2986 (2012).

${ }^{49}$ K. Kobayashi, M. Miki, and S. Tagawa, J. Chem. Soc., Dalton Trans. 17, 2885 (1995).

${ }^{50}$ A. Denicola, B. A. Freeman, M. Trujillo, and R. Radi, Arch. Biochem. Biophys. 333, 49 (1996).

${ }^{51}$ S. Carballal, S. Bartesaghi, and R. Radi, Biochim. Biophys. Acta, Gen. Subj. 1840, 768 (2014).

${ }^{52}$ B. Chance, D. S. Greenstein, and F. J. W. Roughton, Arch. Biochem. Biophys. 37, 301 (1952).

${ }^{53}$ A. Holleman, Recl. Trav. Chim. Pays-Bas Belg. 23, 169 (1904).

${ }^{54}$ J. VasquezVivar, A. Denicola, R. Radi, and O. Augusto, Chem. Res. Toxicol. 10, 786 (1997).

${ }^{55}$ F. Wilkinson and J. G. Brummer, J. Phys. Chem. Ref. Data 10, 809 (1981).

${ }^{56}$ N. Kuzkaya, N. Weissmann, D. G. Harrison, and S. Dikalov, J. Biol. Chem. 278, 22546 (2003).

${ }^{57}$ J. R. Kanofsky, Photochem. Photobiol. 87, 14 (2011).

${ }^{58}$ J. Staehelin and J. Hoigne, Environ. Sci. Technol. 19, 1206 (1985).

${ }^{59}$ J. Korang, I. Emahi, W. R. Grither, S. M. Baumann, D. A. Baum, and R. D. McCulla, RSC Adv. 3, 12390 (2013).

${ }^{60}$ M. C. Sauer, W. G. Brown, and E. J. Hart, J. Phys. Chem. 88, 1398 (1984).

${ }^{61}$ J. Hoigne, H. Bader, W. R. Haag, and J. Staehelin, Water Res. 19, 993 (1985).

${ }^{62}$ K. Hasegawa and P. Neta, J. Phys. Chem. 82, 854 (1978).

${ }^{63}$ A. E. Grigorev, I. E. Makarov, and A. K. Pikaev, High Energy Chem. 21, 99 (1987).

${ }^{64}$ E. L. Thomas, Infect. Immun. 25, 110 (1979).

${ }^{65}$ G. R. Helz and L. Kosakchanning, Environ. Sci. Technol. 18, 48A (1984).

${ }^{66} \mathrm{~S}$. Chemicals, in Dechlorination with Hydrogen Peroxide (Solvay Chemicals, 2005), Vol. H7-166.

${ }^{67}$ V. Aubut, L. Pommel, B. Verhille, T. Orsière, S. Garcia, I. About, and J. Camps, Oral Surg., Oral Med., Oral Pathol., Oral Radiol., and Endodontol. 109, e120 (2010).

${ }^{68}$ C. C. Winterbourn, M. C. Vissers, and A. J. Kettle, Curr. Opin. Hematol. 7, 53 (2000).

${ }^{69}$ A. J. Elliot, Radiat. Phys. Chem. 34, 753 (1989).

${ }^{70}$ V. Nagarajan and R. W. Fessenden, J. Phys. Chem. 89, 2330 (1985).

${ }^{71}$ N. I. O. S. A. Technology, NIST solution data base, 2002, http://kinetics.nist.gov/solution/.

${ }^{72}$ S. Reuter, J. Winter, A. Schmidt-Bleker, D. Schroeder, H. Lange, N. Knake, V. Schulz-von der Gathen, and K. D. Weltmann, Plasma Sources Sci. Technol. 21, 024005 (2012).

${ }^{73}$ R. Bazinette, R. Subileau, J. Paillol, and F. Massines, Plasma Sources Sci. Technol. 23, 035008 (2014). 